\title{
1 Melting the Lithosphere: metasomes as a source for \\ 2 mantle-derived magmas
}

3 Tyrone O. Rooney ${ }^{1}$, Wendy R. Nelson ${ }^{2}$, Dereje Ayalew ${ }^{3}$, Barry Hanan $^{4}$, Gezahegn Yirgu ${ }^{3}$,

4 John Kappelman ${ }^{5,6}$

$5{ }^{1}$ Department of Geological Sciences, Michigan State University, East Lansing, Michigan 48824,

$6 \quad U S A$

$7 \quad{ }^{2}$ Department of Physics, Astronomy \& Geosciences, Towson University, Towson, MD 21252,

$8 \quad$ USA

$9 \quad{ }^{3}$ School of Earth Sciences, Addis Ababa University, Addis Ababa, Ethiopia.

$10{ }^{4}$ Department of Geological Sciences, San Diego State University, San Diego, CA 92182, USA

$11{ }^{5}$ Department of Anthropology, University of Texas at Austin, Austin, Texas 78712, USA.

$12{ }^{6}$ Department of Geological Sciences, The University of Texas at Austin, Austin, Texas 78712,

13 USA.

14

15

\section{ABSTRACT}

17 Peridotite constitutes most of the Earth's upper mantle, and it is therefore unsurprising that most mantle-derived magmas exhibit evidence of past equilibrium with an olivine-dominated source. Although there is mounting evidence for the role of pyroxenite in magma generation within upwelling mantle plumes, a less documented non-peridotite source of melts are metasomatic veins (metasomes) within the lithospheric mantle. Here we present major and trace element analyses of 66 lavas erupted from a small Miocene shield volcano located within the Ethiopian flood basalt province. Erupted lavas are intercalated with lahars and pyroclastic horizons that are 
24 overlain by a later stage of activity manifested in small cinder cones and flows. The lavas form

25 two distinctive petrographic and geochemical groups: (A) an olivine-phyric, low Ti group (1.7-

262.7 wt. $\% \mathrm{TiO}_{2} ; 4.0-13.6$ wt. $\left.\% \mathrm{MgO}\right)$, which geochemically resembles most of the basalts in the

27 region. These low Ti lavas are the only geochemical unit identified in the later cinder cones and

28 associated lava flows. (B) a clinopyroxene-phyric high Ti group (3.1 - 6.5 wt. \% $\mathrm{TiO}_{2} ; 2.8-9.2$

29 wt. \% MgO), which resembles the Oligocene HT-2 flood basalts. This unit is found intercalated

30 with low Ti lavas within the Miocene shield. In comparison to the low Ti group, the high Ti

31 lavas exhibit a profound depletion in $\mathrm{Ni}, \mathrm{Cr}, \mathrm{Al}$, and $\mathrm{Si}$, and significant enrichment in $\mathrm{Ca}, \mathrm{Fe}, \mathrm{V}$,

32 and the most incompatible trace elements. A characteristic negative $\mathrm{K}$ anomaly in primitive-

33 mantle normalized diagrams, and $\mathrm{Na}_{2} \mathrm{O}>\mathrm{K}_{2} \mathrm{O}$, suggest a source rich in amphibole, devoid of

34 olivine, and perhaps containing some carbonate and magnetite. While melt generation during rift

35 development in Ethiopia is strongly correlated with the thermo-chemical anomalies associated

36 with the African Superplume, thermobaric destabilization and melting of mantle metasomes may

37 also contribute to lithospheric thinning. In regions impacted by mantle plumes, such melts may

38 be critical to weakening of the continental lithosphere and the development of rifts.

\section{Introduction}

40 The process of mantle melting is foundational to studies of igneous rock, yet the composition of

41 the melt source within the mantle can be difficult to discern from erupted lava compositions.

42 Evidence from seismic, experimental petrology studies, and detailed examination of mantle

43 xenoliths and ophiolites has resulted in a broad consensus where peridotite constitutes the bulk of

44 the Earth's upper mantle. On the basis of this paradigm, it has been assumed that mantle-derived

45 magmas will exhibit evidence of past equilibrium with a peridotite source, and detailed models

46 outlining the melting modes and intensive parameters of melt generation from peridotite have 
47 been constructed. However, inconsistencies have been recognized when such models are applied

48 to broad datasets due to the subtle differences imposed upon primary melt compositions by mass

49 contribution from mantle lithologies other than peridotite.

50 The acknowledgement that pyroxenite may play a critical role in magma production

51 within upwelling mantle plumes, either through direct melting (Sobolev et al., 2007) or

52 hybridization with surrounding peridotite (Herzberg, 2011), has challenged the conventional

53 assumptions of peridotite-dominated mantle melting mechanisms and has resulted in an

54 increased focus on distinguishing the potential source lithologies of mantle melts. Pyroxenite

55 that is located within upwelling mantle plumes or as rafts within the asthenosphere may

56 dominate the mass contribution to magma production from non-peridotitic source lithologies;

57 however, a less well-documented source of non-peridotite derived magmas lies within the

58 lithospheric mantle. Mantle metasomes are regions of the lithospheric mantle that have been

59 modally or geochemically (cryptically) enriched as a result of chromatographic interaction

60 between upper mantle-derived melts/fluids percolating through pre-existing peridotitic

61 lithospheric mantle. As a result of this interaction, peridotite may become enriched in

62 metasomatic phases such as amphibole or phlogopite, or veins/domains dominated by these

63 metasomatic phases. Initial models developed to account for melting of these enriched

64 metasomatic domains considered modal melting equations which incorporated the surrounding

65 peridotitic matrix (e.g., Späth et al., 2001), however experimental evidence suggests that

66 thermobaric perturbation of mantle metasomes will generate melt that is dominated by the

67 metasomatic phases, with little if any contribution from the surrounding peridotite (Pilet et al.,

68 2008). Mantle metasomes therefore represent another non-peridotite source lithology for melt

69 generation. 
Studies of primary magmas derived from mantle metasomes have some particular

71 challenges in comparison to the more abundant peridotite- and pyroxenite-derived magmas.

72 Firstly, magmas derived from mantle metasomes are more geographically restricted and are

73 typically better represented in regions with thicker lithospheric mantle - such as on the

74 continents. Secondly, melt transport processes may lead to equilibration between metasome-

75 derived melts and the peridotite which constitutes the bulk of the lithospheric mantle (Pilet et al.,

76 2008). Finally, dilution of melts derived from these relatively small-volume domains by

77 asthenospheric-derived lavas may prevent their effective identification in the first instance.

78 Despite such challenges, constraining the fingerprint of magmas derived from mantle metasomes

79 is necessary in order to effectively unravel their potentially important role in lavas formed from

80 the homogenization of contributions from multiple source domains. While small in volume,

81 melts derived from mantle metasomes can exhibit potentially extreme isotopic heterogeneity and

82 have significant concentrations of many incompatible trace elements (Rosenthal et al., 2009),

83 therefore potentially playing an outsized role in the isotopic budget of mixed source lavas

84 (Rogers et al., 1998). Furthermore, the presence of melt with the lithosphere can have an impact

85 on lithospheric stability by focusing strain and facilitating rifting of the lithosphere with

86 significantly less stress (Buck, 2006). Given the low melting point of lithospheric metasomes

87 (Niida and Green, 1999), relatively minor thermobaric perturbation of the lithosphere may

88 facilitate melt generation (Rogers et al., 1998), with a consequential impact on rift development.

89 Here we present a study of the geochemical characteristics of a large suite of lavas which

90 we interpret to be derived from the asthenosphere and an amphibole-dominated mantle

91 metasome located in the lithospheric mantle. Through petrographic, major element and trace

92 element analysis we show distinctive differences between metasome-derived lavas and 
93 contemporaneous asthenosphere-derived lavas in the region. The metasome-derived lavas exhibit

94 little evidence of equilibration with peridotite and therefore represent an unusually pure

95 endmember of a metasomatically-derived magma. We leverage our whole-rock data with high-

96 precision olivine analysis to show that the unusual compositions of these lavas are imparted onto

97 their olivine phenocrysts. We suggest that the thermal perturbation imparted by the Afar plume

98 upon the East African lithosphere destabilized easily-fusible metasomatic veins which had

99 resided at mid-lithospheric depths since the Pan-African subduction event. We conclude that

100 thermobaric perturbation of the continental lithospheric mantle might facilitate rift development

101 through strain focusing associated with the presence of magma within the lithospheric mantle.

102

103

\section{Samples}

104 The samples of the Gerba Guracha series were collected from flows emanating from a distinct

105 edifice near the towns of Fiche and Gerba Guracha to the northwest of Addis Ababa on the

106 western Ethiopian plateau (Fig. 1). In hand specimen, Gerba Guracha series rocks appear fresh,

107 an observation confirmed by petrographic examination revealing broadly unaltered crystals and

108 matrix. One of the most notable petrographic characteristics of the Gerba Guracha lavas are the

109 large (cm-scale) zoned clinopyroxene crystals. Zoning in these crystals may manifest as both

110 sector and fine-scale (possibly oscillatory) zoning (Fig. S1). Crystals are typically set in dark,

111 almost glassy matrix. Glomeroporphyritic textures of mm-scale clinopyroxene and olivine are

112 also observed. There are abundant opaque minerals present which can range up to $1 \mathrm{~mm}$-scale.

113 Zeolite- or carbonate-filled vesicles are evident in hand specimen but were largely avoided

114 during sample collection and billet preparation. Some samples where these vesicles were

115 unavoidable produced values with exceedingly elevated concentrations of Sr (e.g. sample 
$1163222 \mathrm{ves})$. A less common variety of strongly olivine-phyric flows were identified on the floor of

117 the volcanic edifice and appear to post-date the rest of the volcanic activity on the basis of 118 morphology.

\section{Methods}

120 Whole rock geochemical results were derived from hand samples by preparing $\sim 30 \mathrm{~g}$ billets,

121 which were polished to remove saw marks. These billets were then crushed in a steel jaw crusher

122 before being powdered in a BICO flat plate pulverizer that has been fitted with ceramic plates.

123 The resulting powders were fused with lithium tetraborate at a ratio of 1:3 following procedures

124 detailed elsewhere (Rooney et al., 2015). The resulting disks were analyzed for major elements

125 by a Brucker S4 Pioneer XRF at Michigan State University. The glass disks were then analyzed

126 for trace element contents by laser ablation inductively coupled plasma mass spectrometry using

127 a Photon Machine Excimer G2 coupled with a Thermo iCAP-Q at Michigan State University

128 following procedures detailed elsewhere (Rooney et al., 2015). Analytical results and values for

129 standards are provided in Tables S2 and S3.

130 Samples with visible olivine were selected for high precision electron microprobe analysis of 131 minor elements in olivine (Table S4; S5), which was undertaken at Rutgers University using the 132 methods described by Sobolev et al. (2007).

133 Samples of fresh matrix were hand-picked from a single sample and sent for Ar-Ar dating to 134 the Geochronology Laboratory at the University of Michigan under the supervision of Dr. Chris 135 Hall. Analytical details of procedures followed are outlined elsewhere (Rooney et al., 2012a). Ar 136 release spectra for the duplicate analysis are presented in Fig. S3. 


\subsection{Major and Trace elements}

140 To a first order, lava series at Gerba Guracha can be divided on the basis of their geochemical

141 characteristics into a high- and low-Ti group (Table S2). The low-Ti group may be further

142 divided into a silica-undersaturated basanitic group and a sub-alkaline basalt group. The high-Ti

143 group is found dominantly within the elevated portions of the existing edifice (Fig. 1), while the

144 low-Ti group is typically restricted to small flows and cinder cones along the flat floor of the

145 edifice, though there is some evidence of intercalation between low- and high-Ti groups within

146 lahars along the walls (e.g. samples 3267, 3268). This geochemical division is mirrored in a

147 petrographic variation where olivine is more abundant in the low-Ti group, while clinopyroxene

148 is more abundant within the high-Ti group.

\section{4.1.1 High-Ti Group}

150 While the initial division between groups at Gerba Guracha is based upon Ti concentrations,

151 virtually every element exhibits significant differences between the two groups. The high-Ti

152 group has a relatively high value for calculated loss on ignition ( 4-5\%; Table S1), though the

153 samples do not have the appearance of significant alteration. The high-Ti group is particularly

154 deficient in silica, ranging from 0 to $10 \%$ normative nepheline for the more mafic samples,

155 extending to $30 \%$ for more evolved samples (CIPW normalization). High-Ti samples are not

156 particularly alkali-rich; however, the somewhat average alkali contents combined with their low

$157 \mathrm{SiO}_{2}$ contents places them within the foidite, basanite/tephrite, phonotephrite, and

158 tephriphonolite fields (Figure S2). 
161 elevated values of $\mathrm{CaO}, \mathrm{TiO}_{2}, \mathrm{Fe}_{2} \mathrm{O}_{3 \mathrm{~T}}$, and $\mathrm{P}_{2} \mathrm{O}_{5}$ extend beyond the trends typical of all other

162 groups (Fig. 2). There are some similarities between the high-Ti Gerba Guracha group and the

163 Oligocene HT-2 flood basalt group from the northeastern Ethiopian plateau (e.g. low $\mathrm{Al}_{2} \mathrm{O}_{3}$,

164 elevated $\mathrm{Fe}_{2} \mathrm{O}_{3}, \mathrm{TiO}_{2}$ ); however, the Gerba Guracha high-Ti suite extends to significantly lower 165 concentration of $\mathrm{SiO}_{2}$, and higher values of $\mathrm{Fe}_{2} \mathrm{O}_{3}, \mathrm{P}_{2} \mathrm{O}_{5}$ and $\mathrm{CaO}$.

166 Gerba Guracha high-Ti lavas are profoundly depleted in some compatible trace elements

167 (Ni, Cr; Fig. 3), and enriched in V, Zr, and light to medium REE in comparison to many other

168 regional suites at similar $\mathrm{MgO}$ content. Incompatible trace element variation within the Gerba

169 Guracha high-Ti group show a marked variation in incompatible element concentrations at

170 common values for $\mathrm{MgO}$ and extend to some of the most enriched values reported in the region.

171 Primitive mantle normalized trace element patterns (Fig. 4) for the Gerba Guracha high-Ti group

172 exhibit a distinctive enrichment in the most incompatible elements, with the exception of Rb and

$173 \mathrm{~K}$. The characteristic negative $\mathrm{K}$ anomaly and trace element pattern is similar to the Oligocene

174 Ma HT-2 basalts, though the Gerba Guracha series has a greater degree of enrichment in the

175 more incompatible trace elements.

177 The low-Ti group exhibits a range in silica saturation: while the majority of samples have no 178 normative nepheline, a subset parallels the high normative nepheline found within the high-Ti

179 group. This reveals a clear basanite and basalt subdivision within the low-Ti group as evident in 180 the total alkali-silica diagram (Fig. S2). Major element variation within the low-Ti group parallel 181 most of the other regional suites (with the exception of the Oligocene HT-2 basalts noted above) 182 and are therefore significantly different in comparison to the high-Ti suite. 
184 are strongly correlated with $\mathrm{MgO}$ and parallel other regional suites (Fig. 2). In particular there

185 are marked similarities with the Pliocene Akaki basalt group from the margin of the Ethiopian

186 Rift (Rooney et al., 2014a). Rocks from the basanite sub-group typically plot at elevated values

187 of the more incompatible elements. The basalt sub-group of the low-Ti suite exhibits remarkable

188 correlation in primitive-mantle normalized values when compared to the Akaki basalts as noted

189 above and also overlaps the few Miocene shield volcano samples with sufficiently primitive

$190 \mathrm{MgO}$ contents (Fig. 4). The basanite sub-group extends to higher values of more incompatible

191 elements (notably $\mathrm{Nb}-\mathrm{Ta}$ ), and has a steeper slope in the less incompatible trace elements in

192 comparison to the basalt sub-group. In many ways, the basanite sub-group of the low-Ti group

193 shares more similarities with the high-Ti group.

\subsection{Olivine geochemistry}

195 We measured olivine major and minor element abundances in two high-Ti lavas (3187T; 3225), 196 four basanites $(3267 ; 3268 ; 3242 \mathrm{C})$, one low-Ti lava (3761), and one of the underlying

197 Oligocene flood basalts for comparison. Olivine within the high-Ti group is rare, and the results 198 from the two samples presented followed detailed examination of many of the higher $\mathrm{MgO}$ high-

199 Ti samples. The olivine grains in these high-Ti samples exhibit a wide range of Ni (71-830 ppm),

$200 \mathrm{Ca}(1770-3913 \mathrm{ppm})$, and Mn $(1594-3265 \mathrm{ppm})$ over a small compositional range $(\mathrm{Fo}=79-81)$.

201 Olivine from the other samples records a wider range in compositions $\left(\mathrm{Fo}_{66-90}\right)$. Olivine from

202 these other Gerba Guracha units follow Ni and Ca evolutionary trends similar to other regions 203 (e.g., Afar and Hawaii; Fig 5A; B), though for olivine $<\mathrm{Fo}_{80}$ (with the exception of the flood 204 basalts) Mn values extend above simple olivine-clinopyroxene fractionation models (Fig. 5D). 205 The critical results from these data are the broad correlations between the whole-rock values and 
206 the olivine chemistry: (1) The elevated values of $\mathrm{CaO}$ in the whole-rock and olivine datasets are

207 evident in the high-Ti group ; (2) the profoundly low concentrations of Ni recorded in the whole

208 rock data from the high-Ti group is also reflected in the olivine data, effectively discriminating

209 between the basanites and high-Ti olivine (Fig. 5B). These data also reveal evidence of

210 xenocrystic and antecrystic olivine. A subset of the olivine data collected from the basanites

211 form a distinct trend toward the San Carlos standard (Fig. 5E), which may thus reflect some

212 xenocrystic olivine in these samples. Similarly, the high-Ti olivine data are anchored within the

213 basanite trends, suggestive of potentially antecrystic crystals derived from the basanite lavas - a

214 conclusion strengthened by the discovery of an olivine crystal in sample $3187 \mathrm{~T}$ that appears to

215 exhibit characteristics of both the high-Ti olivines and the basanite olivines (phenocryst 2; Table

216 S4).

\subsection{Argon Geochronology}

218 The ${ }^{40} \mathrm{Ar} /{ }^{39} \mathrm{Ar}$ age spectra and replicate analysis are presented in Fig. S3. The age data $(\sim 24-25$

219 Ma) are consistent with the shield-building phase on the western Ethiopian plateau. In particular,

220 this period coincides with activity at the Choke and Guguftu shield volcanoes (Kieffer et al.,

221 2004) and a subset of related dikes along the Afar margin (Rooney et al., 2013). The activity at

222 Gerba Guracha therefore post-dates the main flood basalt phase at 30 Ma (Kieffer et al., 2004),

223 but predates the primary period of extension in the region that commences ca. $20 \mathrm{Ma}$ (Wolfenden

224 et al., 2005) 
228 The low-Ti lavas erupted at Gerba Guracha exhibit major and trace element characteristics

229 consistent with magmatic evolution following a path similar to other lavas from the Ethiopian

230 Cenozoic magmatic province (Fig. 2, 3). We thus assume a dominantly fractional crystallization

231 origin for these evolutionary trends with subordinate contributions from magma mixing and

232 assimilation (e.g., Kieffer et al., 2004; Rooney et al., 2014a). In contrast, the high-Ti magma

233 series occupies an unusual compositional space within the regional dataset, in part overlapping

234 the Oligocene HT-2 lavas of the Ethiopian flood basalts. Previous studies have shown that the

235 evolutionary trends of the HT-2 flood basalts are dominated by deep fractionation of

236 clinopyroxene and olivine, consistent with the phenocryst phases observed in those lavas (Pik et

237 al., 1998). Petrographic evidence of cumulate textures and finely-zoned clinopyroxene crystals in

238 the Gerba Guracha high-Ti group is evidence that these magmas have spent some time residing

239 in the crust while undergoing differentiation. Significant clinopyroxene fractionation is

240 supported by a strong correlation between decreasing $\mathrm{MgO}$, increasing values of $\mathrm{Al}_{2} \mathrm{O}_{3}$, and

241 decreasing $\mathrm{CaO}$ (Fig. 2), and supported by a significant decrease in Sc concentrations at lower

$242 \mathrm{MgO}$ values (Table S1). Unlike the HT-2 flood basalts, olivine is a rare phenocryst phase in the

243 Gerba Guracha high-Ti group. Instead, Fe-Ti oxide removal appears to be a more dominant

244 process contributing to magma evolution - supported by strongly positive correlations between

$245 \mathrm{~V}$ and $\mathrm{Fe}_{2} \mathrm{O}_{3}$ with $\mathrm{MgO}$, and negative correlations with $\mathrm{SiO}_{2}$ (Fig. 3). Vanadium partitions

246 preferential into ilmenite $\left(\mathrm{K}_{\mathrm{D}}=11\right)$ and magnetite $\left(\mathrm{K}_{\mathrm{D}}=0.11-190\right)$ over clinopyroxene $\left(\mathrm{K}_{\mathrm{D}}=\right.$

247 0.05-5), resulting in the preferential removal of V during fractionation of Fe-Ti oxides (Shervais,

248 1982; Zack and Brumm, 1998). The importance of Fe-Ti oxides in controlling trace element

249 partitioning is further support by the ubiquitous presence of Fe-Ti oxides as large crystal phases

250 (Figure S1). Evidence of magma mixing is preserved within the olivine data from the Gerba 
251 Guracha high-Ti magma group (Fig. 5). In particular, these data form arrays that are consistent 252 with mixing of basanite and high-Ti magmas (Fig. 5).

\subsection{Mantle Origin of the Low-Ti Groups}

255 The major and trace element characteristics of the low-Ti lavas from Gerba Guracha match

256 closely the Pliocene Akaki lavas from the western rift margin (Fig. 2, 3). Indeed, the trace

257 element patterns evident in the Gerba Guracha low-Ti and Akaki lavas (Fig. 4) are common in

258 Quaternary lavas found throughout the Main Ethiopian Rift (Rooney et al., 2012b; 2014a). The

$259 \mathrm{Fe} / \mathrm{Mn}$ values of the low-Ti alkaline lavas are elevated above MORB and instead match Fe/Mn

260 values from Akaki and other oceanic islands (Qin and Humayun, 2008), consistent with a plume-

261 influenced mantle source (Fig. 6).

Detailed isotopic studies have shown that lavas from the Main Ethiopian Rift are the

263 result of contributions from a plume source, the depleted upper mantle, and the African

264 lithosphere (e.g., Furman et al., 2006), consistent with estimates of elevated mantle potential

265 temperature (Rooney et al., 2012c). These Ethiopian Rift lavas are considered to be derived from

266 the mixing of melts from the Afar plume and an ambient upper mantle that has been variably

267 contaminated with lithospheric materials (Rooney et al., 2012b). Previous high-precision olivine

268 data from Afar, show that the magmas are likely derived from a dominantly peridotitic source

269 (Fig. 5) (Sobolev et al., 2007). On the basis of their remarkable similarity to lavas from

270 throughout the Main Ethiopian Rift, the low-Ti Gerba Guracha lavas are therefore interpreted to

271 be derived from partial melting of the same largely peridotitic plume-influenced variably

272 contaminated upper mantle source. Similar to other asthenosphere-derived magmatism erupted in 
273 this region over the past $30 \mathrm{Ma}$, we propose that the low-Ti Gerba Guracha magmas are

274 generated by sub-lithospheric melts caused by excess mantle potential temperature and

275 decompression as a result of lithospheric thinning (e.g., Furman et al., 2006; Rooney et al.,

276 2012a,b,c, 2014).

$278 \quad 5.3$ Potential Asthenospheric Origins of the Gerba Guracha High-Ti Group

279 5.3.1 Possible Peridotite Source?

280 Gerba Guracha high-Ti magmas are distinguished from other African-Arabian volcanic suites by

281 their high $\mathrm{CaO}$ and $\mathrm{Fe}_{2} \mathrm{O}_{3 \mathrm{~T}}$ values as well as their low $\mathrm{Al}_{2} \mathrm{O}_{3}$ and $\mathrm{SiO}_{2}$ abundances. These

282 features have been recognized previously as key major element signatures of HIMU magmas

283 globally (e.g., Dasgupta et al., 2010), and consistent with the HIMU-like isotopic characteristics

284 of these lavas (Rooney et al., 2014b). While low silica and elevated iron concentrations have

285 been associated with greater depth of melting in a peridotite source, it is difficult to generate the

286 broad range of major element characteristics of HIMU by partial melting of a volatile-free

287 peridotite (Dasgupta et al., 2010). Melting a water-fluxed peridotite will result broadly in

288 magmas with lower iron and elevated silica contents (Gaetani and Grove, 1998), while silica-

289 deficient magmas may be generated by $\mathrm{CO}_{2}$-fluxed partial melting of peridotite due in part to the

290 enhanced stability of orthopyroxene under these conditions (e.g., Brey et al., 2008).While

291 melting of a carbonated peridotite is a plausible mechanism to explain most of the geochemical

292 characteristics of the Gerba Guracha high-Ti lavas, the elevated values of $\mathrm{TiO}_{2}$ (Fig. 7),

293 relatively modest alkali concentrations, and position within the Ne-Di-Ol ternary (Fig. 8)

294 precludes this origin (e.g., Pilet et al., 2008). 
296 Pyroxenites (including eclogites) have been identified as a subordinate yet pervasive component 297 within the mantle ( 10\%: Gerbode and Dasgupta, 2010). The origin of these components has 298 been linked to subducted oceanic crust (basalts and gabbros) and delaminated continental 299 lithosphere that is converted into garnet, clinopyroxene, a free $\mathrm{SiO}_{2}$ phase, and variable amounts 300 of orthopyroxene (e.g., Herzberg, 2011). However, experimental melting results of nominally 301 volatile-free pyroxenites show that the experimental melts are too enriched in alkalis and 302 insufficiently enriched in titanium to explain the origin of the high-Ti Gerba Guracha lavas (Fig. 303 7).

Partial melting of carbonated MORB-like pyroxenites (protoliths that are relatively high

305 in silica) can produce some of the major element features of HIMU-like primary magmas:

306 specifically where deep melting initially occurs at $\sim 6 \mathrm{GPa}$ (Gerbode and Dasgupta, 2010) and is

307 followed by a complex series of processes that involve solid-state interaction and reaction of 308 pyroxenite (or derived melts) with surrounding peridotite to form a hybrid lithology that 309 subsequently melts to produce HIMU-like magmas (e.g., Herzberg, 2011). Pyroxenite melts that 310 have reacted with peridotite may also have similarities to HIMU-like magmas (Mallik and 311 Dasgupta, 2012). Similarly, melting of carbonated, silica-deficient pyroxenites at moderate 312 depths ( $\sim 3 \mathrm{GPa})$ create major element compositions similar to the high-Ti Gerba Guracha suite 313 (Dasgupta et al., 2006) (Fig. 7, 8). Given the array of potential lithologies from which mantle-derived magmas may 315 originate, minor elements in olivine phenocrysts have increasingly been used to probe the 316 composition of primary magmas from which the olivine crystallized and, by extension, the 
317 lithology that melted to form the primary melt (Sobolev et al., 2007; Herzberg, 2011; Herzberg et

318 al., 2014). Initially, Ni content of olivine was used to probe the contributions of peridotite and

319 pyroxenite to derivative mantle melts: high $\mathrm{Ni}$ values in magmatic olivine were theorized to

320 represent pyroxenite-derived melts, while lower values were attributed to peridotite melts

321 (Sobolev et al., 2007). Further evidence for pyroxenite contribution was evident where low $\mathrm{Ca}$

322 and Mn abundances in olivine were cited as evidence of pyroxenite melting (Sobolev et al.,

323 2007). With the growing realization that pyroxenite, peridotite, and their respective derivative

324 melts may interact to form a complex array of hybrid sources and magmas (e.g., Herzberg, 2011;

325 Mallik and Dasgupta, 2012), olivine source determinations have evolved from a binary

326 peridotite/pyroxenite predictive model to one where substantial ranges in lithological variation

327 are possible (Herzberg, 2011).

The high precision analysis of Gerba Guracha olivine shows significant heterogeneity in

329 the minor elements over a limited Fo range (Fig. 5). However, the most significant division is

330 evident between the low-Ti and high-Ti groups: (A) The low-Ti group olivine crystals plot in a

331 region such that they could be derived from a melt of a peridotite source that experienced

332 dominantly clinopyroxene fractionation, or a hybrid pyroxenite-peridotite source partially

333 depleted in olivine and clinopyroxene removal (Fig. 5). The compositional trends of these

334 crystals are consistent with data from the underlying flood basalt olivine and from other plume

335 environments. (B) Heterogeneities within the composition of olivine from the high-Ti group are

336 noted above to be derived from a mix of low-Ti crystals and an endmember unique to the high-Ti

337 group. This endmember is defined by profoundly low $\mathrm{Ni}$ and very high $\mathrm{Ca}$ concentrations, and is

338 unlike any other olivine in the database. These results mirror the whole rock data of the high-Ti

339 group, which shows enrichment in $\mathrm{CaO}$ and depletion in $\mathrm{Ni}$ (Fig. 2, 3). 
341 implications for the interpretation of their origin. Previous studies have suggested that high $\mathrm{Ni}$

342 contents in olivine phenocrysts were indicators of melt derived from melting of pyroxenites, as

343 the lack of olivine in the mantle source (and its high $\mathrm{K}_{\mathrm{D}}$ for $\mathrm{Ni}$ ) resulted in melts and olivine

344 phenocrysts with Ni concentrations that are elevated above peridotite melts and derivative

345 olivine (Sobolev et al., 2007). However, olivine in the somewhat alkaline Gerba Guracha lavas is

346 depleted in Ni. It also notable that clinopyroxene and not olivine is the dominant mafic phase in

347 Gerba Guracha high-Ti lavas. The preferential removal of clinopyroxene would only serve to

348 deplete the Ni concentration in the remaining magma to an even lesser degree, making the

349 mismatch between Gerba Guracha and other regional lava suites even more pronounced. Low Ni

350 contents in olivine have been previously attributed to potential sequestration in a sulfide phase

351 (Herzberg, 2011). However, the observed depletion in the high-Ti Gerba Guracha lavas of both a

352 chalcophile (Ni) and lithophile (Cr) element (Fig. 3) is inconsistent with the sequestration of $\mathrm{Ni}$

353 by sulfide formation in a regular mantle-derived magma. We therefore conclude that the hybrid

354 pyroxenite-peridotite processes described above are entirely inappropriate to describe the origin 355 of high-Ti Gerba Guracha lavas.

\section{$357 \quad 5.4$ Lithospheric mantle origins of the High-Ti Group}

\subsubsection{Generation and destruction of lithospheric metasomes}

359 Previous isotopic studies of the Gerba Guracha high-Ti group suggested a source within the

360 lithospheric mantle which has been isolated since the Pan-African assembly of the lithosphere in 361 this region (Rooney et al., 2014b). The formation of this source is considered the result of the 
362 interaction between the lithospheric mantle and asthenospheric melts/liquids derived from both

363 peridotite and pyroxenite sources (e.g., Pilet et al., 2008). Within the deeper lithosphere

364 (>100km), migrating metasomatic fluids/melts may generate anhydrous cumulate veins;

365 surrounding these veins, enrichment of the existing peridotite may take the form of modal

366 metasomatism (i.e. phlogopite) or cryptic enrichment (e.g., Bedini et al., 1997). At shallower

367 depths, hydrous cumulate suites dominated by amphibole will form (Stein et al., 1997).

368 Experimental evidence suggests that the major element composition of amphibole within

369 hydrous metasomatic veins does not exhibit significant melt composition-dependent variance

370 (except Ti) (e.g., Pilet et al., 2008). Thus, despite the wide range in possible compositions of the

371 initial metasomatic agent, the ultimate result is a metasomatized mantle characterized by a

372 stratified assemblages of hydrous and anhydrous metasomatic minerals (e.g., Pilet et al., 2008).

373 The solidi of hydrous veins are substantially depressed compared to that of anhydrous

374 peridotite (e.g., Pilet et al., 2008), making the veins a potentially important source of melt.

375 Experimental and modeled partial melts of metasomatic veins hosted within the lithospheric

376 mantle have been shown to closely resemble OIB magmas, despite the wide variety of phases

377 present within these enriched lithospheric zones (Pilet et al., 2008; Pilet et al., 2011). These

378 experimental studies have shown that incongruent melting of amphibole dominates the melt

379 reactions in such systems, such that similar melt compositions are derived from a wide variety of

380 hydrous metasomatic assemblages (Pilet et al., 2008). Importantly, the melting of amphibole-rich

381 lithologies produces nepheline-normative magmas (Médard et al., 2006) such as observed in the

382 high-Ti Gerba Guracha lavas. The Gerba Guracha high-Ti lavas follow similar trends (Fig. 7) to

383 the experimental melts of natural hornblendite and clinopyroxene-hornblendite at $1.5 \mathrm{GPa}$ over a

384 range of temperatures (Pilet et al., 2008), with some discrepancies: (i) at common values of $\mathrm{SiO}_{2}$, 
385 iron in the experimental melts is lower than observed which may be due to melting of small

386 amounts of magnetite (Médard et al., 2006); and (ii) $\mathrm{Al}_{2} \mathrm{O}_{3}$ and $\mathrm{CaO}$ discrepancies may indicate a

387 role for some residual garnet. Importantly, hornblendite experimental melts yield appropriate

388 titanium and alkali contents to be a potential source of the Gerba Guracha high-Ti lavas (Fig. 7).

389 Thus, experimental melts of carbonated amphibole-rich lithologies broadly correlate with the

390 major and trace element characteristics of the Gerba Guracha magmas and support an origin for

391 these magmas as a melt of a mantle metasome containing phases such as amphibole, sphene, Fe-

392 Ti oxides, and minor carbonate (Pilet et al., 2008).

The strong enrichment in incompatible trace elements of the high-Ti lavas in comparison

394 to other regional magma suites may further support a metasomatic origin for these lavas.

395 Hydrous cumulate veins, which form subsequent to the anhydrous assemblages, contain

396 significant enrichment in incompatible elements (e.g., Pilet et al., 2008), typically concentrated

397 in accessory phases (e.g., apatite, illmenite, allanite, zircon, and titanite). The trace element

398 characteristics of the hydrous metasomatic veins are largely controlled by the partition

399 coefficients and mass of minor metasomatic phases within a vein, and are not particularly

400 sensitive to the composition of the original melt/liquid which formed such veins (Pilet et al.,

401 2011). The relatively large degree of melting within the hydrous veins (in comparison with a

402 peridotite) results in magmas that have trace element characteristics broadly similar to their

403 source vein, though slightly more enriched (Pilet et al., 2008; Pilet et al., 2011). Ultimately,

404 magmas derivative of hydrous metasomatic veins may exhibit similar major element

405 characteristics controlled by incongruent melting of amphibole, but considerable variation in

406 trace element concentrations that are dependent on the type and mass of accessory phases within

407 a particular source vein. Trace element patterns similar to that observed for the Gerba Guracha 
408 suite (Fig. 9) can be produced through models simulating melting of hydrous cumulates with 0-

$4092 \%$ rutile, illmenite, titanite, allanite, apatite, sulfide, and zircon (Pilet et al., 2011).

4115.5 Constraints on the mineralogy of the metasome: Oxygen fugacity, garnet, and the role

412 of Fe-Ti oxides.

413 The high-Ti group exhibits elevated concentrations of first-row transition elements (FRTE), and

414 unusual fractionation of these elements during magma differentiation (Fig. 6). These

415 characteristics can provide insight into the mineralogy of the metasomatic veins and the intensive

416 parameters imposed upon the derivative melt (i.e. oxygen fugacity). The whole-rock Fe/Mn

417 ( 40-110) of the high-Ti group extends to values that are significantly above and below the

418 typical range of MORB and OIB (Fe/Mn 50-75) (Qin and Humayun, 2008; Davis et al., 2013),

419 and is significantly more scattered than other magma suites in the region (Fig. 6). The Fe/Mn

420 range in the high-Ti group is not imposed by unusually high or low values of Fe or Mn; indeed

421 the concentrations of both these elements exceeds that of other regional suites (Fig. 3). Instead,

$422 \mathrm{Fe} / \mathrm{Mn}$ is positively correlated with $\mathrm{MgO}$, suggesting control of iron oxide fractionation, which is

423 ubiquitous in the high-Ti group even at higher $\mathrm{MgO}$ values. This assertion is consistent with the

424 observation of a parallel depletion in V concentrations (Fig. 3). Thus, unlike most magmatism in

425 Ethiopia, the Gerba Guracha high-Ti lava suite follows a fraction path more typical of magmas

426 characterized by significantly higher $\mathrm{fO}_{2}$. Given the evidence for the early stabilization of

427 magnetite, the $\mathrm{fO}_{2}$ is likely on the order of arc magmas (QFM+1 to 2). Such observations are

428 consistent with highly alkaline rocks (e.g., carbonatites) from elsewhere in the East African rift 
429 where magnetite is an early, and volumetrically important, fractionating phase (e.g., Guzmics et 430 al., 2015).

The initially high concentration of $\mathrm{Fe}, \mathrm{Mn}$ and Fe/Mn in the high-Ti lavas is not typical

432 of peridotite melts (Fig. 6). Hydrous melting of garnet peridotite can elevate Fe/Mn values (Balta 433 et al., 2011), however, the whole-rock and olivine Fe/Mn values observed extend beyond that 434 likely to be derived from peridotite melt (Herzberg, 2011). Higher values of Fe/Mn in melts are 435 possible in source lithologies with more garnet and less olivine, such as a pyroxenite (Balta et al., 436 2011) or garnet-bearing amphibolite. While the influence of garnet in the high-Ti group source is 437 seemingly supported by elevated V/Sc (Davis et al., 2013), V/Yb (Laubier et al., 2014), and 438 apparent fractionation of $(\mathrm{Tb} / \mathrm{Yb})_{\mathrm{CN}}\left(\right.$ Fig. 6), on close inspection we see that $(\mathrm{Tb} / \mathrm{Yb})_{\mathrm{CN}}$ is 439 uncorrelated with V/Sc and Fe/Mn. Furthermore, the REE values for the more primitive high-Ti 440 lavas (>7\% $\mathrm{MgO})$ show substantially parallel MREE and HREE patterns ( $\mathrm{Tb}-0.97-1.85 ; \mathrm{Yb}-$ 441 1.36-2.89), contrasting with the compression of the more incompatible REEs evident in magmas 442 derived from variable degrees of melting of a garnet-bearing hornblendite on primitive mantle 443 normalized diagrams (e.g., Ma et al., 2011). We instead suggest a two-step mechanism to explain 444 the fractionated REEs: (A) a metasomatic melt/fluid is generated by partial melting of a lithology 445 containing garnet. This melt/fluid percolates up through the lithospheric mantle and creates a 446 metasomatic vein with depleted HREE. (B) Subsequent melting of the garnet-free metasomatic 447 vein will yield magmas with fractionated HREE. This mechanism is supported by experimental 448 results from melting of garnet-free HREE depleted hornblendite lithologies, which have 449 produced melts with fractionated $(\mathrm{Tb} / \mathrm{Yb})_{\mathrm{CN}} 2-3$ and parallel REE patterns (Pilet et al., 2008), 450 similar to that observed in our high-Ti group. Magmas derived from metasomatic veins may thus 451 have fractionated HREE without the direct influence of garnet in their source, with resulting 
452 implications for the use of apparent 'garnet signatures' in establishing the intensive parameters of 453 magmagenesis in such magmas.

454 On the basis that garnet is not a controlling phase in the source of the high-Ti group, the 455 unusual concentrations of FRTEs (e.g., Ti, Sc, Fe, V, Mn) in these lavas remains unexplained.

456 We have previously noted that these elements are strongly controlled by the early appearance 457 and fractionation of iron oxides during magma evolution, suggesting a higher $\mathrm{fO}_{2}$ in these lavas 458 and raising the question: was the mantle source of the high-Ti group unusually oxidized? Over

459 the past decade significant attention to mantle oxidation states has highlighted a substantial 460 degree of uncertainty as to the possible cause (or indeed existence) of oxidized domains within 461 the mantle (e.g., Brounce et al., 2015). Regardless of the precise mechanism for driving high $f \mathrm{O}_{2}$ 462 in subduction-related magmas, the interaction of such high $\mathrm{fO}_{2}$ magmas with the overlying 463 lithospheric mantle results in the formation of amphibole-rich metasomes where spinel has been 464 converted to Ti-rich magnetite (Blatter and Carmichael, 1998), resulting in elevated values of $f \mathrm{O}_{2}$

465 in the sub-arc mantle (FMQ up to +4: Evans et al., 2012). We therefore suggest that the high 466 apparent $\mathrm{fO}_{2}$ in the high-Ti lavas is inherited from its metasomatic source - a Pan-African 467 subduction-influenced lithospheric mantle (Rooney et al., 2014b).

\section{$468 \quad 5.6$ Tectonic Implications}

469 Prior investigation of the Gerba Guracha high-Ti group has revealed an unusual isotopic 470 signature that approaches the HIMU reservoir (Rooney et al., 2014b). This signature is quite 471 distinctive from other lavas erupted during the Oligocene flood basalt event and subsequent rift472 related volcanism, which are dominated by the "C", depleted mantle, and lithospheric reservoirs 473 (Rooney et al., 2012b). In contrast, the HIMU-like signature evident in the high-Ti group 
474 resembles lavas erupted in northeast Africa and Arabia, distant from the locus of the Afar plume

475 (Fig. 1). Prior studies have shown that this HIMU-like signature likely results from in-situ 476 evolution of a metasomatically enriched lithospheric mantle metasome emplaced during the Pan-

477 African subduction event (Rooney et al., 2014b). The potentially widespread presence of an 478 easily-fusible metasome within the Pan-African lithosphere, has implications for lithospheric 479 stability and rift development throughout the region.

Amphibole-bearing metasomes, which have the potential to melt at significantly lower 481 temperatures in comparison to peridotite (Pilet et al., 2008), may become destabilized by 482 thinning or thermo-mechanical erosion of the continental lithospheric mantle. The presence of 483 magma within the continental lithospheric mantle can facilitate weakening and lead to further 484 destabilization of the lithosphere (Buck, 2006). The initial interaction of a mantle plume with the 485 lithospheric mantle may provide the impetus needed to melt lithospheric metasomes, however, 486 the eruption of the Gerba Guracha lavas $\sim 5 \mathrm{Ma}$ after the flood basalt episode had terminated 487 presents difficulties for this model. While large volumes of flood basalt passed through the 488 continental lithosphere during the Oligocene, studies of lithospheric mantle xenoliths beneath the 489 northwestern Ethiopian plateau suggest that the transit of flood basalts was likely focused into 490 distinct channels (Roger et al., 1999), allowing for the preservation of metasomes away from 491 such channels. The 24 Ma eruption of the Gerba Guracha series occurred during an unusually quiescent 493 period, immediately preceding the development of rifting at this latitude (Wolfenden et al., 494 2005), thus raising the question of how the Gerba Guracha magmas might have been generated? 495 Given the lack of evidence for lithospheric stretching at this time (e.g., Wolfenden et al., 2005), 496 and the improbability of thermo-mechanical erosion of the lithosphere during this period due to 
497 low magma flux (Rooney et al., 2013), we consider thermal perturbation of the continental

498 lithospheric mantle as a mechanism to destabilize lithospheric metasomes (Fig. 10). Studies from

499 the western branch of the EAR suggest that some early silica-undersaturated alkaline magmas

500 erupted there also lack a clear extensional causation and were instead generated by thermal

501 destabilization of lithospheric metasomes (Rogers et al., 1998). Over a ca. 10 Ma period, plume-

502 resultant conductive heating of the lithospheric mantle melted the metasomatized lithosphere and

503 generated magmas observed in the Virunga province (Rogers et al., 1998). For the Gerba

504 Guracha area, eruption occurs ca. 7-9 Ma after the initial manifestations of Cenozoic magmatism

505 in this region and we explore the potential for heating of the lithosphere in this region. We

506 presume an initial lithospheric thickness of $\sim 120 \mathrm{~km}$ (Dugda et al., 2007), and the maximum

507 pressure limits for pargasitic amphibole (in a peridotite matrix - we are unaware of equivalent

508 high pressure amphibolite experiments) of $\sim 90 \mathrm{~km}$ (Niida and Green, 1999). On the basis of a

509 continental geotherm of $50 \mathrm{~mW} / \mathrm{m}^{2}$, the continental lithosphere at $90 \mathrm{~km}$ would be $\sim 920^{\circ} \mathrm{C}$,

510 significantly below the $1075^{\circ} \mathrm{C}$ stability limit for pargasitic amphibole (Niida and Green, 1999).

511 Using the formulation of Turner et al., (1996), where a $300^{\circ} \mathrm{C}$ increase in mantle potential

512 temperature was imposed upon the base of the lithosphere, the region of the lithosphere $30 \mathrm{~km}$

513 from the lithospheric base increased $\sim 140^{\circ} \mathrm{C}$ over $9 \mathrm{Ma}$, approaching the $1075^{\circ} \mathrm{C}$ amphibole

514 stability limit. This model of progressive lithospheric thermal destabilization is supported by

515 xenolith-based geotherms for the Ethiopian plateau that suggest that at $5 \mathrm{Ma}$, the lithosphere at

$51690 \mathrm{~km}$ depth was $\sim 1166^{\circ} \mathrm{C}$ (Conticelli et al., 1999). 


\section{Conclusions}

520 The thermal perturbation of the East African lithosphere by the Afar plume destabilized easily-

521 fusible metasomes at mid-lithospheric depths. These metasomes, which had resided in the

522 lithospheric mantle since the Pan-African subduction event, were likely carbonated and

523 dominated by amphibole and Fe-Ti oxides. Melts derived from these metasomes erupted at $\sim 24$

524 Ma on the Ethiopian plateau and had distinctive geochemical characteristics in comparison to

525 contemporaneously erupted low-Ti lavas that resemble others lavas in the region. Gerba Guracha

526 high-Ti magmas are distinguished by being silica-undersaturated, rich in incompatible trace

527 elements and most first-row transition elements, but profoundly depleted in Ni and $\mathrm{Cr}$. The high

528 oxygen fugacity imparted by the mineralogy of the source metasome resulted in the early

529 appearance of Fe-Ti oxides in the derivative melts. The presence of metasomes that may

530 generate melt upon thermobaric perturbation of the continental lithosphere has implications for

531 our understanding of long-term lithospheric stability, given the potential for such melts to focus

532 strain and facilitate rift development. The conceptual model we present herein opens

533 opportunities for further studies to constrain the volume of melt generated by this process, and in

534 assessing its role in modifying the lithospheric strain profile during the initiation of rifting.

\section{7. Acknowledgements}

536 Funding: This work was supported by the United States National Science Foundation [EAR-

537 1219647]. We gratefully acknowledge the analytical support of Chris Hall for the argon

538 geochrononology and Chris Vidito, Juliane Gross, and Claude Herzberg for the high-precision

539 olivine work. We would like to thank Ananya Mallik and Kurt S. Panter for reviews, and the

540 careful editorial handling of Mike Bickle which improved the manuscript. 


\section{FIGURES}

$543 \quad$ Figure 1.

544 Location of study within the East African Rift system. (A) Regional Cenozoic volcanism divided

545 into small-volume intra-plate activity (blue) and flood basalts/rift basalts (red). (B) Topography

546 and the outline of the border faults of the Main Ethiopian Rift (MER) in addition to the

547 quaternary volcanic centers along the Wonji Fault Belt. Also shown is the quaternary Silti-Debre

548 Zeyit Fault Zone (SDFZ), and Pliocene Akaki chain. The Miocene shield volcanoes of Choke

549 and Guguftu are also shown (Kieffer et al., 2004). (C) Digital elevation model of the Gerba

550 Guracha edifice derived from Shuttle Radar Topography Mission data. This perspective image

551 has 4x vertical exaggeration and shows sampling localities. Red squares are high-Ti lavas, blue

552 squares are low-Ti lavas localities.

554 Figure 2.

555 Variance of major element oxides for Gerba Guracha lavas shown against mafic lavas from other 556 regional suites: 
$561 \quad$ (Rooney et al., 2013).

562 All data presented as weight percent and normalized to $100 \%$.

564 Figure 3.

565 Variance of selected trace element for Gerba Guracha lavas shown against the same lava suites 566 referenced in Figure 2.

$567 \quad$ Figure 4.

568 Primitive mantle normalized (Sun and McDonough, 1989) trace element diagram showing the

569 Gerba Guracha lavas in comparison to the Oligocene HT-2 flood basalts, Pliocene Akaki, and

570 Miocene shield volcano lavas (see Figure 2 for data sources). All samples are greater than 7wt.

$571 \% \mathrm{MgO}$.

572

$573 \quad$ Figure 5.

574 Olivine from the Gerba Guracha lavas shown plotted against OIB and MORB suites from the

575 high precision database of Soblev et al. (2007). Fields shown are calculated for olivine from

576 primary and derivative peridotite melts (Herzberg, 2011). Note that 'flood basalt' here refers to a 577 sample of the Ethiopian Flood basalts collected below the Gerba Guracha units.

578 A. Ni versus forsterite (Fo) content of Gerba Guracha magmas and other suites. Grey field 579 are for olivine crystals derived from hybridized pyroxenite sources. 
B. Ni versus Fo, same suites as in A but scale is adjusted to log to show the degree of Ni depletion at Gerba Guracha

C. Mn values versus Fo content of Gerba Guracha olivine compared to other suites. Shown are a series of models simulating the impact of clinopyroxene and olivine fractionation on the path of an evolving primitive magma. fractionation strongly leverages the Ca content of olivine to lower concentrations.

Figure 6.

591 Variations of the first row transition elements (FRTE) in the Gerba Gurcaha lavas.

592 A) Previous studies have noted the inaccuracy of MnO measurements by XRF (Qin and 593 Humayun, 2008), we therefore present data collected on the same sample disks by XRF and 594 LA-ICPMS. The agreement between the XRF and LA-ICPMS results is good and, given the 595 large range in Fe/Mn ratios, we thus assert that the XRF data is sufficient. their elevation in $\mathrm{V} / \mathrm{Sc}$ may in part be the result of increased $f \mathrm{O}_{2}$ in their mantle source.

599 Fields for modeled melts of eclogite $($ grey $=$ altered oceanic crust, dotted $=$ MORB $)$, melt of 600 peridotite (dark grey), and primitive OIB (dashed line) are from Davis et al., (2013). 
$601 \mathrm{C} \& \mathrm{D})$ There is strong control of $\mathrm{MgO}$ on the $\mathrm{Fe} / \mathrm{Mn}$ and $\mathrm{V} / \mathrm{Sc}$ values in the High-Ti suite. This 602 contrasts with the high precision MORB and OIB suites (Qin and Humayun, 2008), and the 603 well-constrained Pliocene Akaki suite (Rooney et al., 2014a) for Fe/Mn. For more primitive 604 lavas (8-12 wt. \% MgO), V/Sc has been used to infer $f \mathrm{O}_{2}$ values in the mantle source (Lee et 605 al., 2005). For a 10\% partial melt of a spinel lherzolite, the V/Sc values in the low-Ti group 606 plot approximately within the QFM domain (Lee et al., 2005). The high-Ti V/Sc values could 607 be produced by increasing $f \mathrm{O}_{2}$ values of the same mantle source $(\mathrm{QFM}+2)$, or a $5 \%$ partial 608 melt of a garnet-bearing source with similar $f \mathrm{O}_{2}$ to the low-Ti group. Lee et al., (2005) 609 specifically caution against using such models to make determinations of $f \mathrm{O}_{2}$ in cases where 610 metasomatic veins may have contributed to melt (such as Gerba Guracha). In such cases, 611 smaller degrees of melting, residual garnet, differing initial V and Sc concentrations and 612 exotic phases obscure the role of $f \mathrm{O}_{2}$. However, the plots illustrate the potential influence of 613 both $\mathrm{fO}_{2}$ and garnet on the geochemical systematics of the Gerba Guracha lavas.

$614 \mathrm{E} \& \mathrm{~F})$ Plot of $\mathrm{V} / \mathrm{Sc}$ and $\mathrm{Fe} / \mathrm{Mn}$ versus an index of garnet in the source $(\mathrm{Tb} / \mathrm{Yb}$ - chondrite 615 normalized) for primitive lavas (>7wt. \% MgO) from Gerba Guracha. No strong correlation 616 between $\mathrm{V} / \mathrm{Sc}, \mathrm{Fe} / \mathrm{Mn}$, and $\mathrm{Tb} / \mathrm{Yb}$ is observed, making a clear determination of the presence 617 of garnet in the source of these lavas equivocal (Lee et al., 2005; Davis et al., 618 2013).Enhanced $f \mathrm{O}_{2}$ may also have also contributed to the observed variability in first row 619 transition elements. 
622 Major element data from primitive Gerba Guracha samples plotted with experimentally derived

623 melts from a variety of mantle materials. All data is presented as weight percent and normalized

624 on a volatile free basis to $100 \%$. We have not plotted experimental data where the volatile-free

625 total is lower than $75 \%$, or the data point is a significant outlier. Citations to the data sources

626 used may be found in the supplemental material. We have selected 7 wt. \% $\mathrm{MgO}$ as a lower filter

627 for our data on the basis of experimental work by Pilet et al., (2008). These authors have shown

628 that primary melts derived from the melting of hornblendite have ca. $6.9 \mathrm{wt} . \%$ to $11.9 \mathrm{wt} \%$.

$629 \mathrm{MgO}$. Gerba Guracha samples with $>7$ wt. \% MgO may represent primary melts and it is thus

630 appropriate to compare them with experimentally derived primary melts. The final panel depicts

$631 \mathrm{TiO}_{2}$ vs total alkalis and has been previously used to separate melts derived from carbonated

632 peridotites and eclogites/hornblendites (Zeng et al., 2010).

633 Figure 8

634 CIPW normalization plotted on the Ne+Lc (nepheline + leucitite), Ol (olivine), Di (diopside), Hy

635 (hypersphene), Q (quartz). CIPW normalization was completed using the assumption that $90 \%$ of

636 the total iron was in the form FeO for consistency with previous datasets. Fields for experimental

637 melting data as outlined in Figure 7. We have selected 7 wt. \% $\mathrm{MgO}$ as a lower filter for our

638 data as in Figure 7.

639 Figure 9

640 Primitive mantle normalized McDonough \& Sun (1995) trace element diagram showing the

641 Gerba Guracha lavas in comparison to a model range of melts produced from metasomatized

642 hydrous lithosphere composed of hydrous veins plus 0-5\% trapped liquid (Pilet et al., 2011). The 
643 red line is the high-Ti Gerba Guracha median value for samples are greater than $7 \mathrm{wt} . \% \mathrm{MgO}$;

644 the two yellow lines are 1 standard deviation from this median.

645 Figure 10

646 Conceptual model where metasomatism during the Pan-African event enriched the continental

647 lithospheric mantle forming amphibole rich veins within the lithospheric mantle. During the late

648 Oligocene and Miocene, thermal destabilization of the continental lithospheric mantle by

649 interaction with the Afar plume created melts from these metasomes. Contemporaneous with

650 this, low-Ti magmas were generated from broadly the same asthenospheric reservoirs as modern

651 day lavas in the Main Ethiopian Rift. The basanites may be a mixture of the lithospheric and

652 asthenospheric reservoirs.

653

654

655 


\section{References}

657

658

659

660

661

662

663

664

665

666

667

668

669

670

671

672

673

674

675

676

677

678

679

680

681

682

683

684

685

686

687

688

689

690

691

692

693

694

695

696

697

698

699

700
Balta, J.B., Asimow, P.D., and Mosenfelder, J.L., 2011, Manganese partitioning during hydrous melting of peridotite: Geochimica Et Cosmochimica Acta, v. 75, p. 5819-5833.

Beccaluva, L., Bianchini, G., Natali, C., and Siena, F., 2009, Continental flood basalts and mantle plumes: a case study of the Northern Ethiopian Plateau: Journal of Petrology, v. 50, p. 1377-1403.

Bedini, R.M., Bodinier, J.L., Dautria, J.M., and Morten, L., 1997, Evolution of LILE-enriched small melt fractions in the lithospheric mantle; a case study from the East African Rift: Earth and Planetary Science Letters, v. 153, p. 67-83.

Blatter, D.L., and Carmichael, I.S., 1998, Hornblende peridotite xenoliths from central Mexico reveal the highly oxidized nature of subarc upper mantle: Geology, v. 26, p. 1035-1038.

Brey, G.P., Bulatov, V.K., Girnis, A.V., and Lahaye, Y., 2008, Experimental Melting of Carbonated Peridotite at 6-10 GPa: Journal of Petrology, v. 49, p. 797-821.

Brounce, M., Kelley, K.A., Cottrell, E., and Reagan, M.K., 2015, Temporal evolution of mantle wedge oxygen fugacity during subduction initiation: Geology, v. 43, p. 775-778.

Buck, W.R., 2006, The role of magma in the development of the Afro-Arabian rift system, in Yirgu, G., Ebinger, C., and Maguire, P., eds., The Afar Volcanic Province within the East African Rift System, Volume 259, Special Publication of the Geological Society, London, p. 43-54.

Conticelli, S., Sintoni, M.F., Abebe, T., Mazzarini, F., and Manetti, P., 1999, Petrology and geochemistry of ultramafic xenoliths and host lavas from the Ethiopian Volcanic Province; an insight into the upper mantle under eastern Africa: Acta Vulcanologica, v. 11, p. 143-159.

Dasgupta, R., Hirschmann, M.M., and Stalker, K., 2006, Immiscible transition from carbonaterich to silicate-rich melts in the $3 \mathrm{GPa}$ melting interval of eclogite $\mathrm{CO} 2$ and genesis of silica-undersaturated ocean island lavas: Journal of Petrology, v. 47, p. 647-671.

Dasgupta, R., Jackson, M.G., and Lee, C.-T.A., 2010, Major element chemistry of ocean island basalts - Conditions of mantle melting and heterogeneity of mantle source: Earth and Planetary Science Letters, v. 289, p. 377-392.

Davis, F.A., Humayun, M., Hirschmann, M.M., and Cooper, R.S., 2013, Experimentally determined mineral/melt partitioning of first-row transition elements (FRTE) during partial melting of peridotite at 3GPa: Geochimica Et Cosmochimica Acta, v. 104, p. 232 260.

Dugda, M.T., Nyblade, A.A., and Julia, J., 2007, Thin lithosphere beneath the Ethiopian plateau revealed by a joint inversion of Rayleigh wave group velocities and receiver functions: Journal of Geophysical Research-Solid Earth, v. 112, p. B08305, doi:10.1029/2006JB004918.

Evans, K., Elburg, M., and Kamenetsky, V., 2012, Oxidation state of subarc mantle: Geology, v. 40, p. 783-786.

Furman, T., Bryce, J.G., Rooney, T., Hanan, B.B., Yirgu, G., and Ayalew, D., 2006, Heads and tails: 30 million years of the Afar plume, in Yirgu, G., Ebinger, C., and Maguire, P., eds., The Afar Volcanic Province within the East African Rift System, Volume 259, Special Publication of the Geological Society, London, p. 95-120.

Gaetani, G.A., and Grove, T.L., 1998, The influence of water on melting of mantle peridotite: Contributions to Mineralogy and Petrology, v. 131, p. 323-346. 
Gerbode, C., and Dasgupta, R., 2010, Carbonate-fluxed Melting of MORB-like Pyroxenite at 2 center dot $9 \mathrm{GPa}$ and Genesis of HIMU Ocean Island Basalts: Journal of Petrology, v. 51, p. 2067-2088.

Guzmics, T., Zajacz, Z., Mitchell, R.H., Szabó, C., and Wälle, M., 2015, The role of liquidliquid immiscibility and crystal fractionation in the genesis of carbonatite magmas: insights from Kerimasi melt inclusions: Contributions to Mineralogy and Petrology, v. 169 , p. 1-18.

Herzberg, C., 2011, Identification of Source Lithology in the Hawaiian and Canary Islands: Implications for Origins: Journal of Petrology, v. 52, p. 113-146.

Herzberg, C., Cabral, R., Jackson, M., Vidito, C., Day, J., and Hauri, E., 2014, Phantom Archean crust in Mangaia hotspot lavas and the meaning of heterogeneous mantle: Earth and Planetary Science Letters, v. 396, p. 97-106.

Kieffer, B., Arndt, N., Lapierre, H., Bastien, F., Bosch, D., Pecher, A., Yirgu, G., Ayalew, D., Weis, D., Jerram, D.A., Keller, F., and Meugniot, C., 2004, Flood and shield basalts from Ethiopia: Magmas from the African superswell: Journal of Petrology, v. 45, p. 793-834.

Laubier, M., Grove, T.L., and Langmuir, C.H., 2014, Trace element mineral/melt partitioning for basaltic and basaltic andesitic melts: an experimental and laser ICP-MS study with application to the oxidation state of mantle source regions: Earth and Planetary Science Letters, v. 392, p. 265-278.

Lee, C.-T.A., Leeman, W.P., Canil, D., and Li, Z.-X.A., 2005, Similar V/Sc systematics in MORB and arc basalts: implications for the oxygen fugacities of their mantle source regions: Journal of Petrology, v. 46, p. 2313-2336.

Ma, G.S.-K., Malpas, J., Xenophontos, C., and Chan, G.H.-N., 2011, Petrogenesis of Latest Miocene-Quaternary Continental Intraplate Volcanism along the Northern Dead Sea Fault System (Al Ghab-Homs Volcanic Field), Western Syria: Evidence for Lithosphere-Asthenosphere Interaction: Journal of Petrology, v. 52, p. 401-430.

Mallik, A., and Dasgupta, R., 2012, Reaction between MORB-eclogite derived melts and fertile peridotite and generation of ocean island basalts: Earth and Planetary Science Letters, v. 329, p. 97-108.

McDonough, W.F., and Sun, S.-S., 1995, The composition of the Earth: Chemical Geology, v. 120, p. 223-253.

Médard, E., Schmidt, M.W., Schiano, P., and Ottolini, L., 2006, Melting of Amphibole-bearing Wehrlites: an Experimental Study on the Origin of Ultra-calcic Nepheline-normative Melts: Journal of Petrology, v. 47, p. 481-504.

Niida, K., and Green, D.H., 1999, Stability and chemical composition of pargasitic amphibole in MORB pyrolite under upper mantle conditions: Contributions to Mineralogy and Petrology, v. 135, p. 18-40.

Pik, R., Deniel, C., Coulon, C., Yirgu, G., Hofmann, C., and Ayalew, D., 1998, The northwestern Ethiopian Plateau flood basalts. Classification and spatial distribution of magma types: Journal of Volcanology and Geothermal Research, v. 81, p. 91-111.

Pik, R., Deniel, C., Coulon, C., Yirgu, G., and Marty, B., 1999, Isotopic and trace element signatures of Ethiopian flood basalts; evidence for plume-lithosphere interactions: Geochimica et Cosmochimica Acta, v. 63, p. 2263-2279.

Pilet, S., Baker, M.B., Müntener, O., and Stolper, E.M., 2011, Monte Carlo Simulations of Metasomatic Enrichment in the Lithosphere and Implications for the Source of Alkaline Basalts: Journal of Petrology, v. 52, p. 1415-1442. 
Pilet, S., Baker, M.B., and Stolper, E.M., 2008, Metasomatized Lithosphere and the Origin of Alkaline Lavas: Science, v. 320, p. 916-919.

Qin, L., and Humayun, M., 2008, The Fe/Mn ratio in MORB and OIB determined by ICP-MS: Geochimica Et Cosmochimica Acta, v. 72, p. 1660-1677.

Roger, S., Dautria, J.M., Coulon, C., Pik, R., Yirgu, G., Michard, A., Legros, P., and Ayalew, D., 1999, An insight on the nature, composition and evolution of the lithospheric mantle beneath the north-western Ethiopian Plateau; the ultrabasic xenoliths from the Tana Lake Province: Acta Vulcanologica, v. 11, p. 161-168.

Rogers, N.W., James, D., Kelley, S.P., and de Mulder, M., 1998, The generation of potassic lavas from the eastern Virunga Province, Rwanda: Journal of Petrology, v. 39, p. 12231247.

Rooney, T., Hart, W., Hall, C., Ayalew, D., Ghiorso, M., Hidalgo, P., and Yirgu, G., 2012a, Peralkaline magma evolution and the tephra record in the Ethiopian Rift: Contributions to Mineralogy and Petrology, v. 164, p. 407-426.

Rooney, T.O., Bastow, I.D., Keir, D., Mazzarini, F., Movsesian, E., Grosfils, E.B., Zimbelman, J.R., Ramsey, M.S., Ayalew, D., and Yirgu, G., 2014a, The protracted development of focused magmatic intrusion during continental rifting: Tectonics, v. 33, p. 875-897.

Rooney, T.O., Hanan, B.B., Graham, D.W., Furman, T., Blichert-Toft, J., and Schilling, J.-G., 2012b, Upper Mantle Pollution during Afar Plume-Continental Rift Interaction: Journal of Petrology, v. 53, p. 365-389.

Rooney, T.O., Herzberg, C., and Bastow, I.D., 2012c, Elevated mantle temperature beneath East Africa: Geology, v. 40, p. 27-30.

Rooney, T.O., Mohr, P., Dosso, L., and Hall, C., 2013, Geochemical evidence of mantle reservoir evolution during progressive rifting along the western Afar margin: Geochimica Et Cosmochimica Acta, v. 102, p. 65-88.

Rooney, T.O., Morell, K.D., Hidalgo, P., and Fraceschi, P., 2015, Magmatic consequences of the transition from orthogonal to oblique subduction in Panama: Geochemistry, Geophysics, Geosystems, v. 16, p. 4178-4208.

Rooney, T.O., Nelson, W.R., Dosso, L., Furman, T., and Hanan, B., 2014b, The role of continental lithosphere metasomes in the production of HIMU-like magmatism on the northeast African and Arabian plates: Geology, v. 42, p. 419-422.

Rosenthal, A., Foley, S.F., Pearson, D.G., Nowell, G.M., and Tappe, S., 2009, Petrogenesis of strongly alkaline primitive volcanic rocks at the propagating tip of the western branch of the East African Rift: Earth and Planetary Science Letters, v. 284, p. 236-248.

Shervais, J.W., 1982, Ti-V plots and the petrogenesis of modern and ophiolitic lavas: Earth and Planetary Science Letters, v. 59, p. 101-118.

Sobolev, A.V., Hofmann, A.W., Kuzmin, D.V., Yaxley, G.M., Arndt, N.T., Chung, S.L., Danyushevsky, L.V., Elliott, T., Frey, F.A., Garcia, M.O., Gurenko, A.A., Kamenetsky, V.S., Kerr, A.C., Krivolutskaya, N.A., Matvienkov, V.V., Nikogosian, I.K., Rocholl, A., Sigurdsson, I.A., Sushchevskaya, N.M., and Teklay, M., 2007, The amount of recycled crust in sources of mantle-derived melts: Science, v. 316, p. 412-417.

Späth, A., Le Roex, A.P., and Opiyo-Akech, N., 2001, Plume-lithosphere interaction and the origin of continental rift-related alkaline volcanism; the Chyulu Hills volcanic province, southern Kenya: Journal of Petrology, v. 42, p. 765-787.

Stein, M., Navon, O., and Kessel, R., 1997, Chromatographic metasomatism of the ArabianNubian lithosphere: Earth and Planetary Science Letters, v. 152, p. 75-91. 
793 Sun, S.s.-., and McDonough, W.F., 1989, Chemical and isotopic systematics of oceanic basalts: 794 Implications for mantle composition and processes., in Saunders, A.D., ed., Magmatism 795 in the ocean basins, Geological Society of London Special Publication 42, p. 313 - 345.

796 Wolfenden, E., Ebinger, C., Yirgu, G., Renne, P.R., and Kelley, S.P., 2005, Evolution of a

797 volcanic rifted margin: Southern Red Sea, Ethiopia: Geological Society of America 798 Bulletin, v. 117, p. 846-864.

799 Zack, T., and Brumm, R., 1998, Ilmenite/liquid partition coefficients of 26 trace elements 800 determined through ilmenite/clinopyroxene partitioning in garnet pyroxene, Proceedings of the 7th International Kimberlite Conference. Cape Town: Red Roof Design, p. 986988.

Zeng, G., Chen, L.-H., Xu, X.-S., Jiang, S.-Y., and Hofmann, A.W., 2010, Carbonated mantle sources for Cenozoic intra-plate alkaline basalts in Shandong, North China: Chemical Geology, v. 273, p. 35-45.

806 

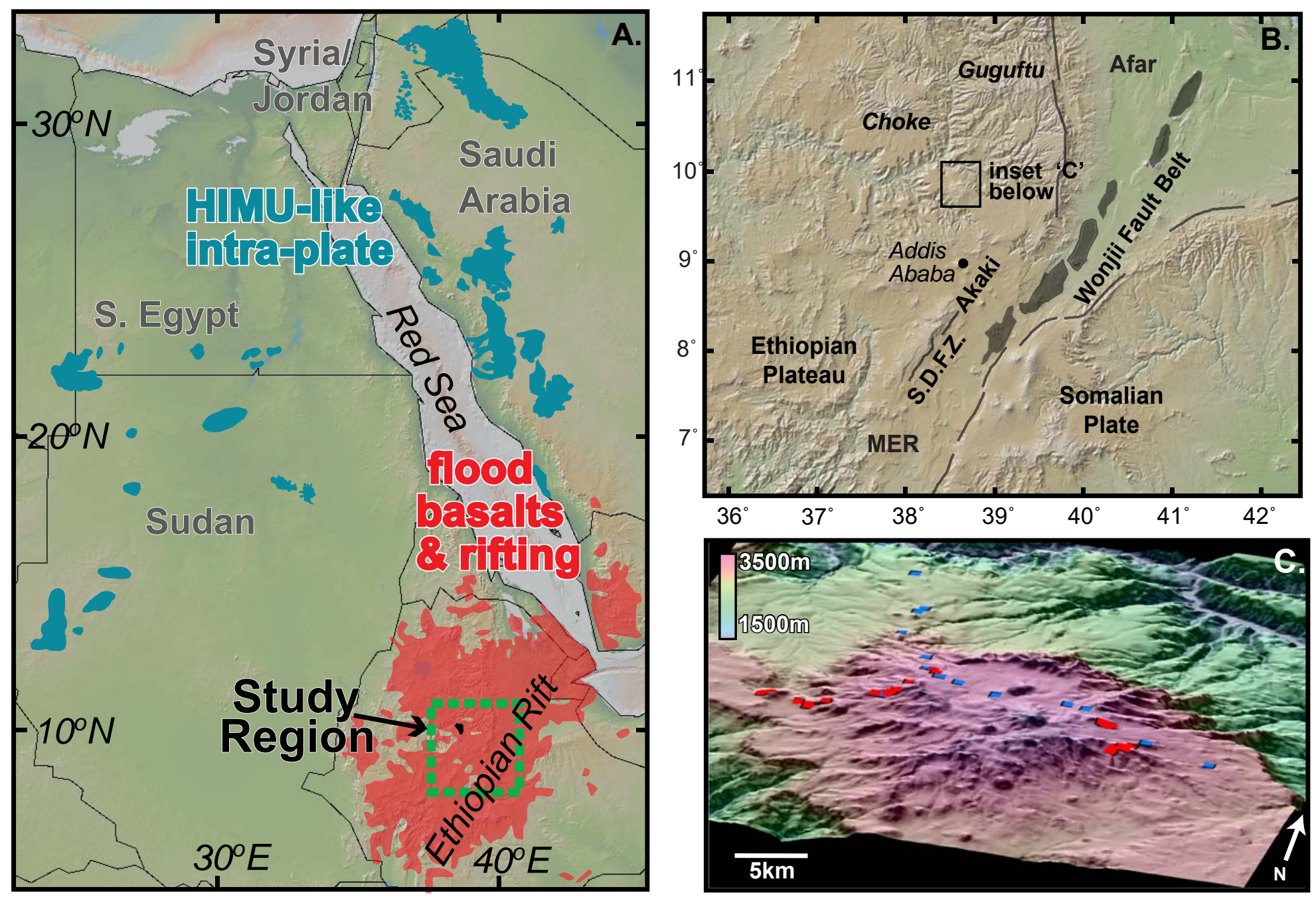

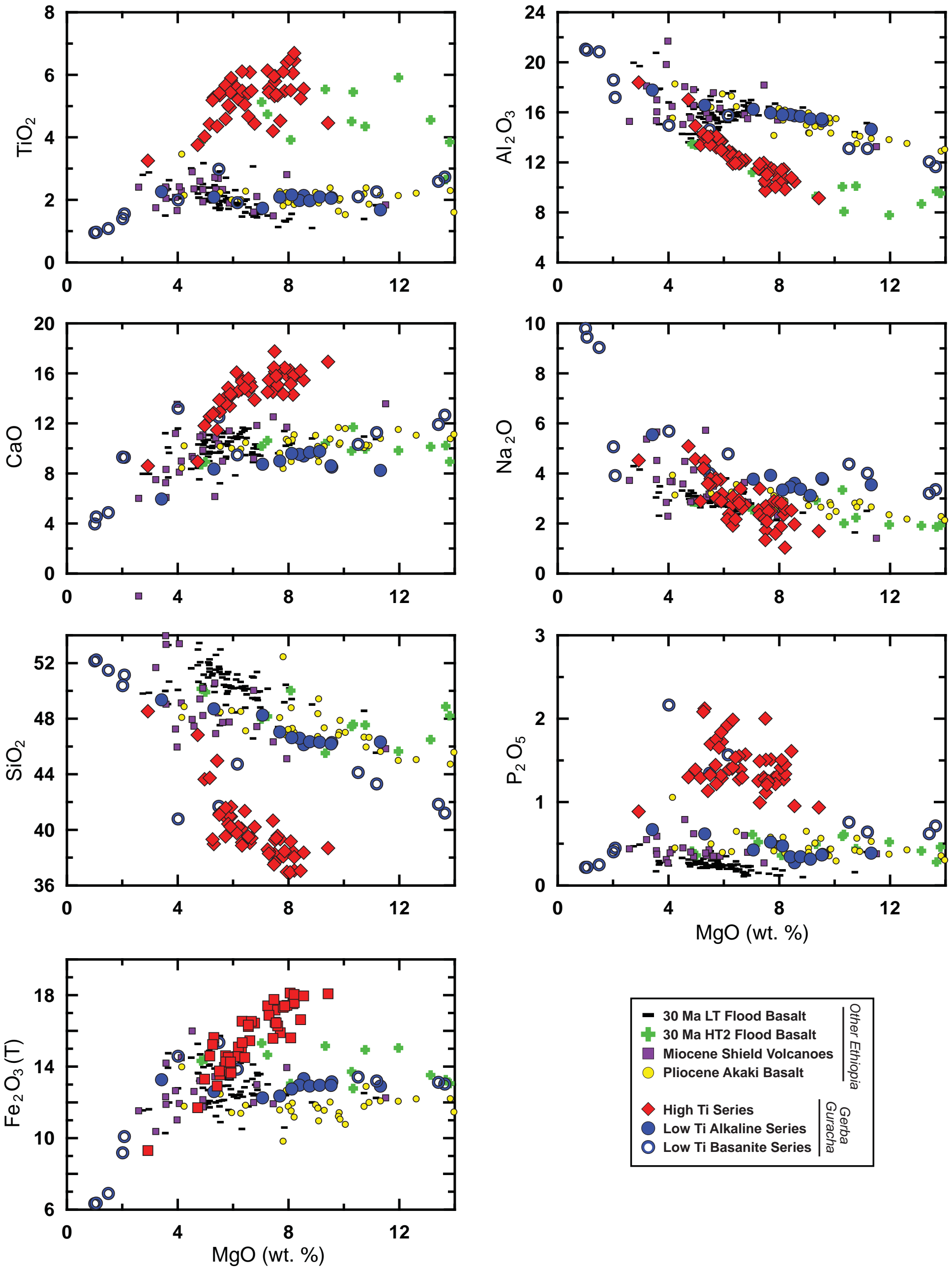

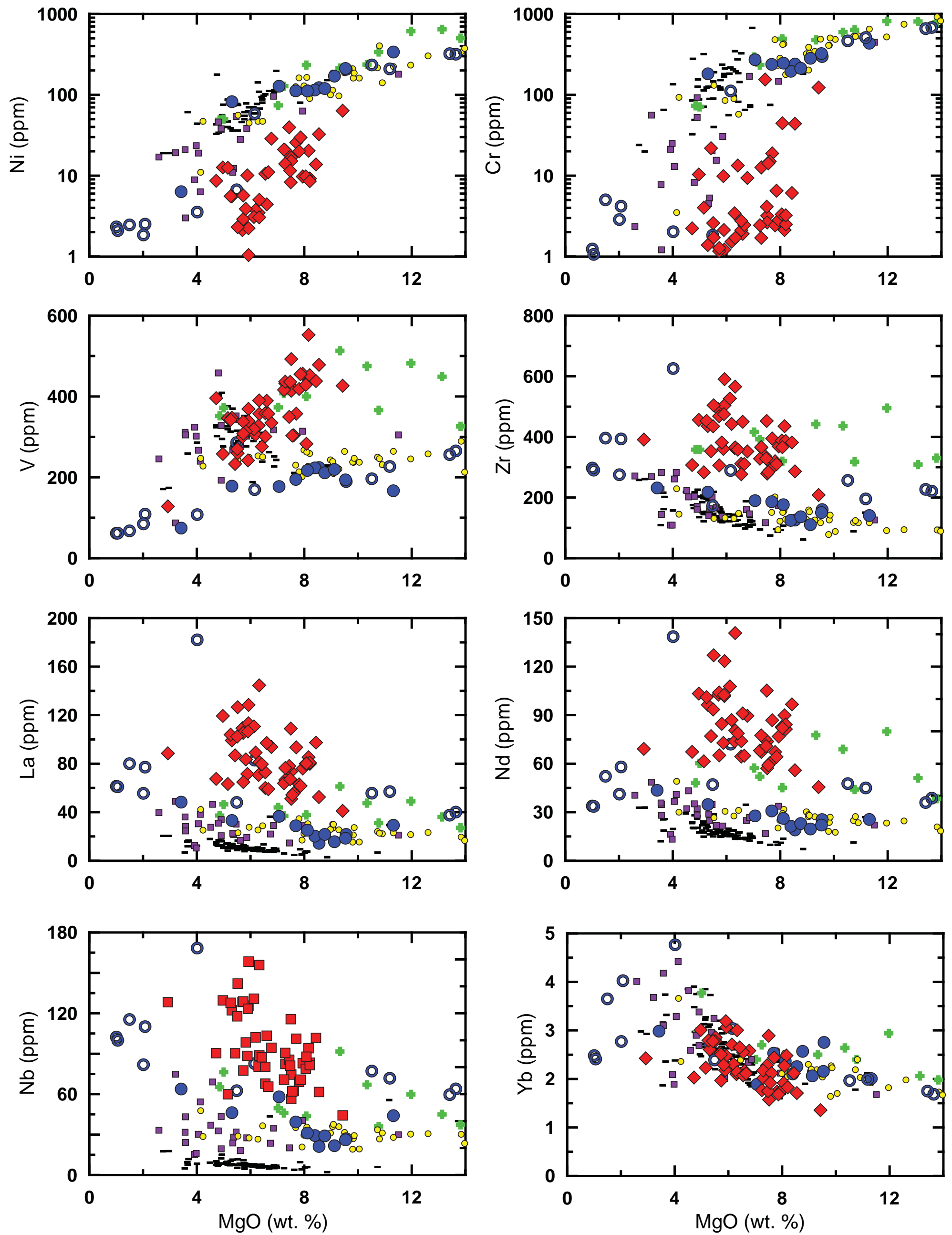


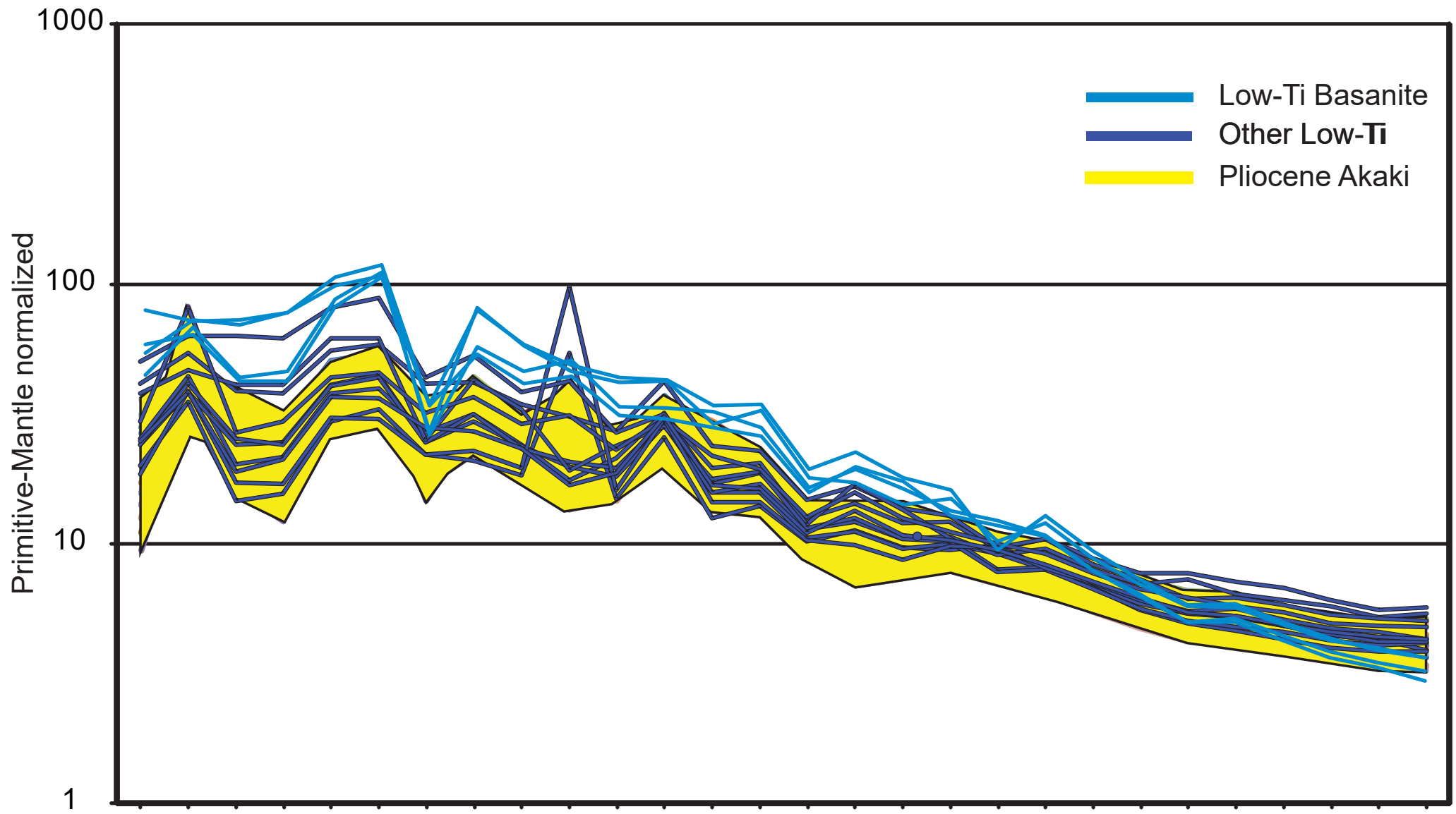

$\mathrm{Rb}$ Ba Th U Nb Ta K La Ce Pb Pr Sr P Nd Sm Zr Hf Eu Ti Gd Tb Dy Y Ho Er Tm Yb Lu

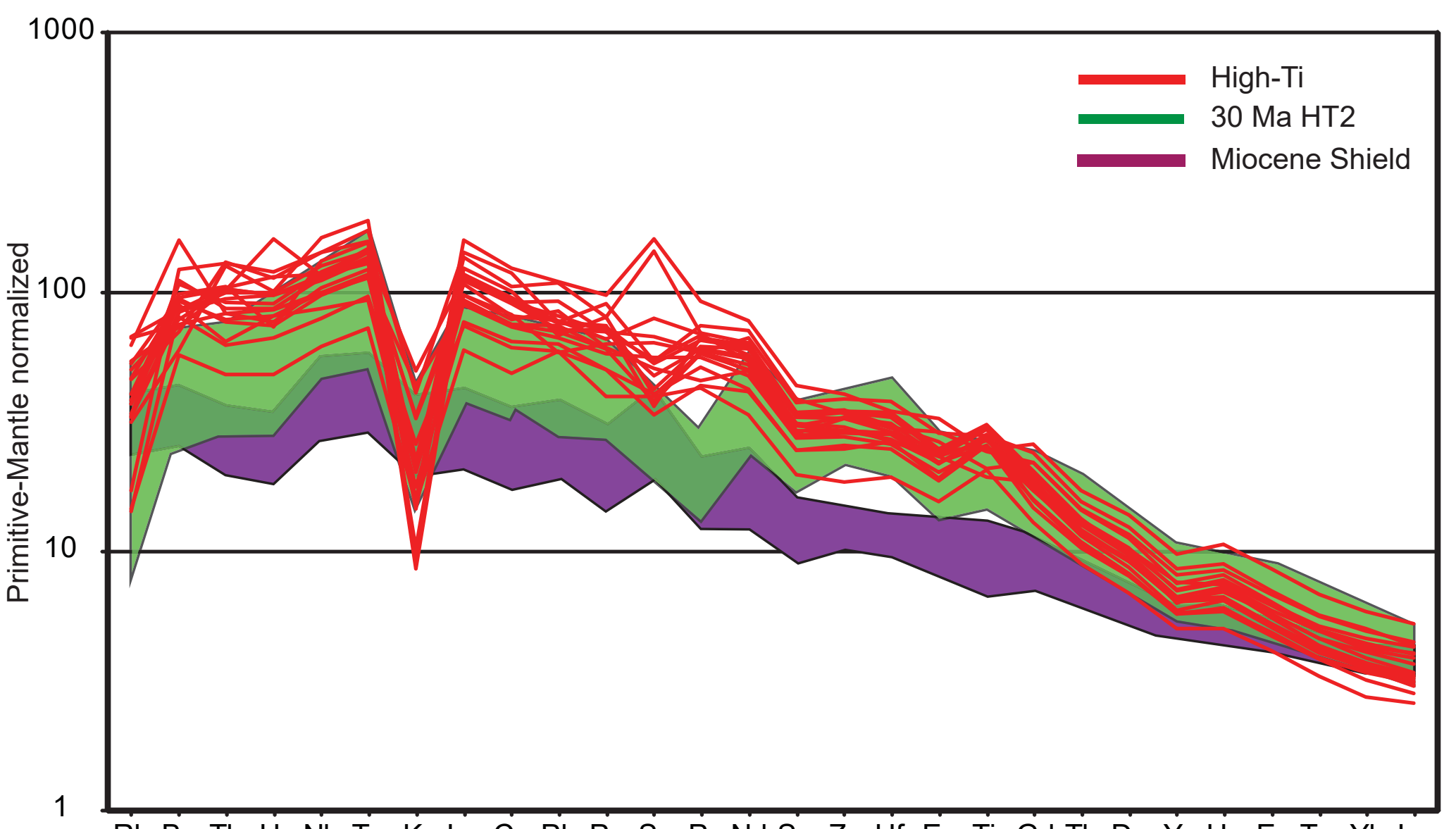

Rb Ba Th U Nb Ta K La Ce Pb Pr Sr P Nd Sm Zr Hf Eu Ti Gd Tb Dy Y Ho Er Tm Yb Lu 

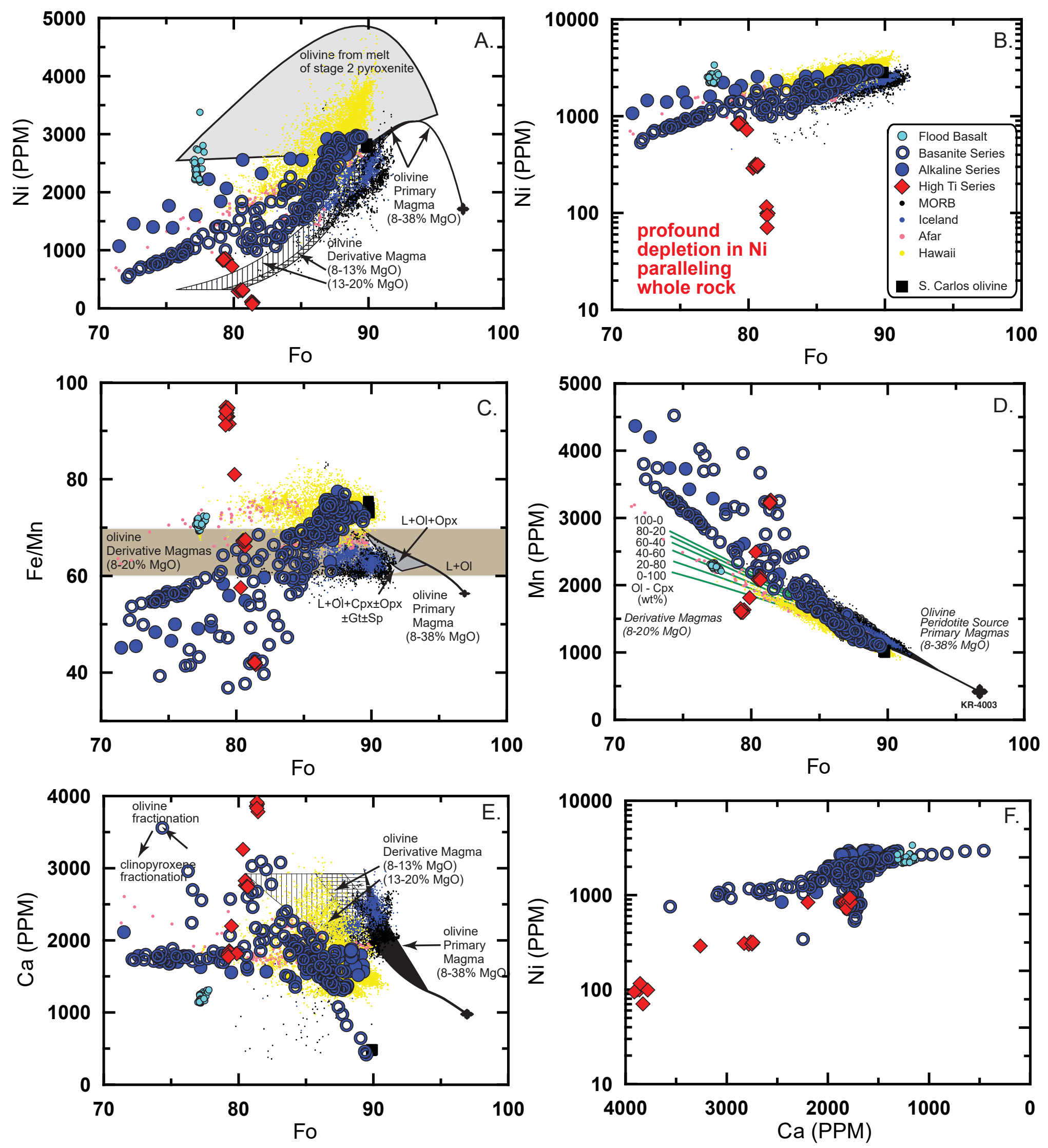

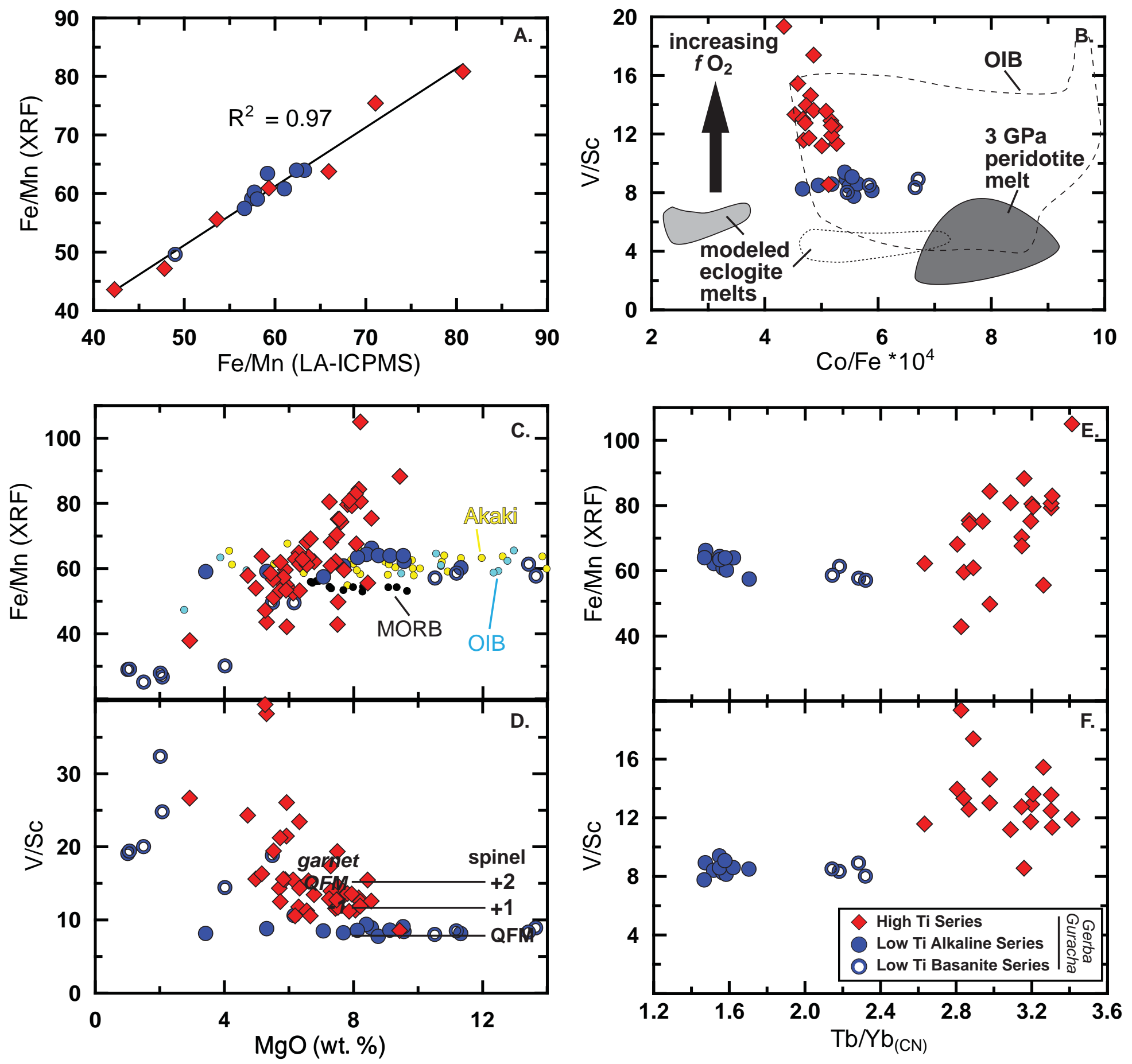

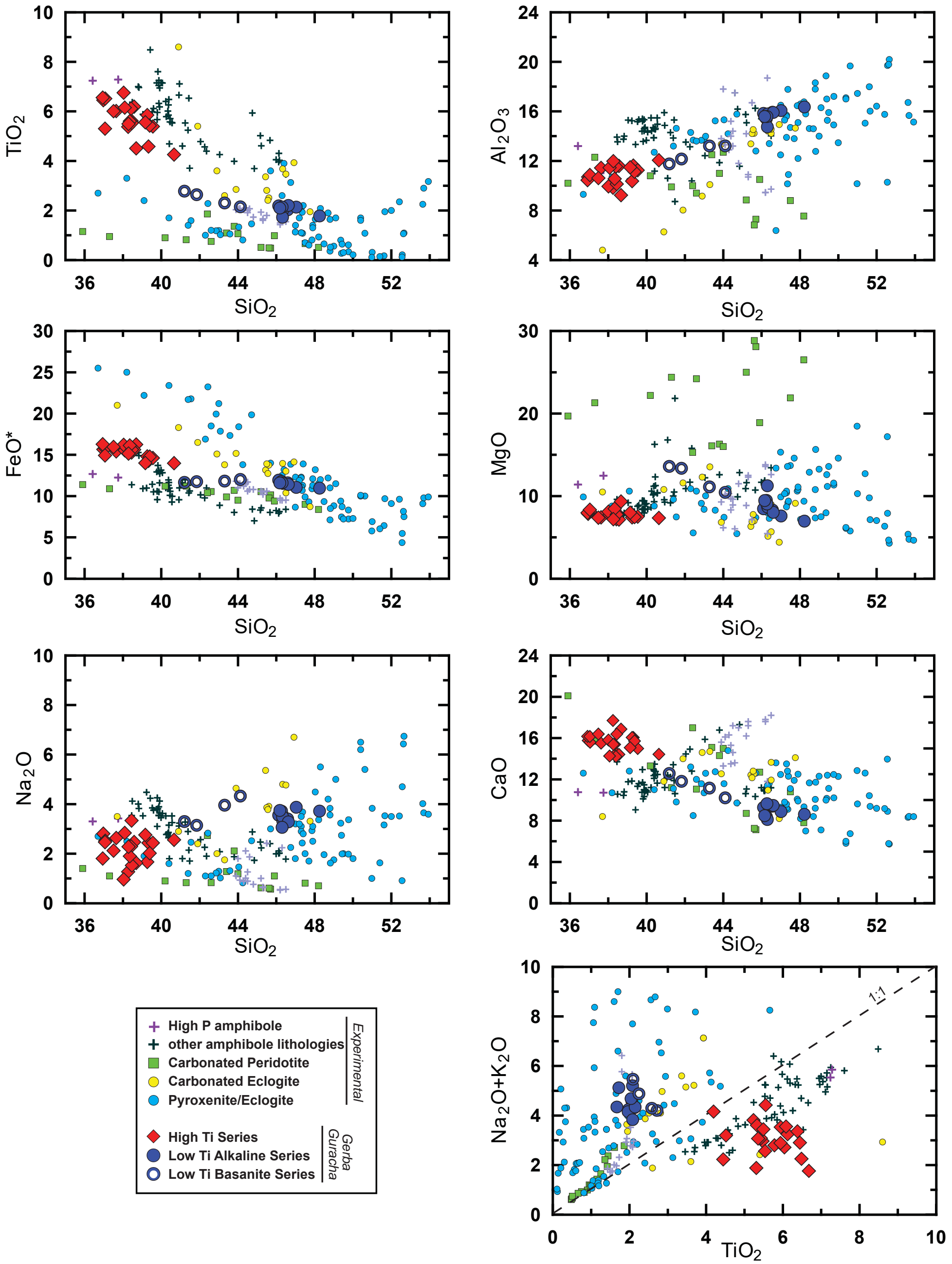


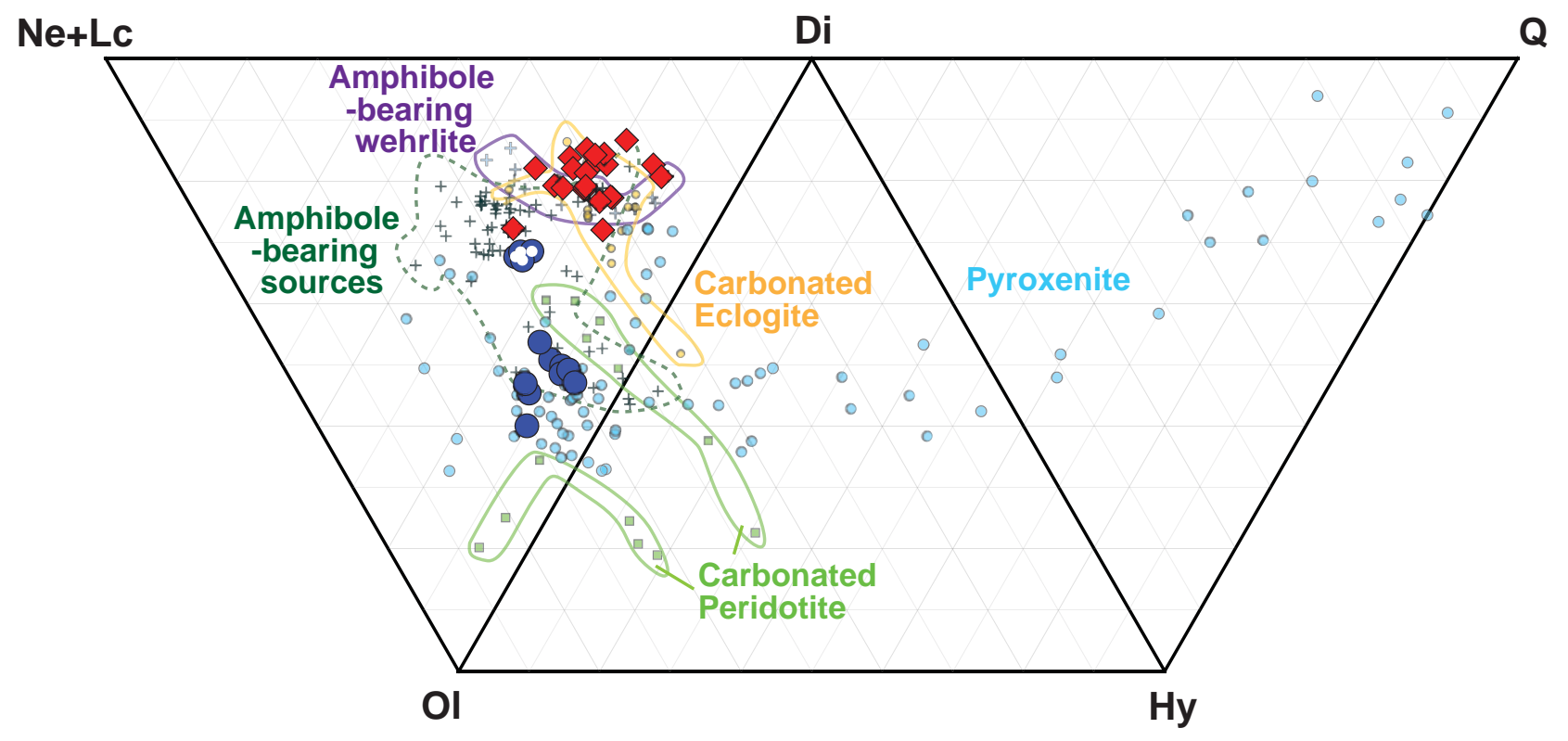




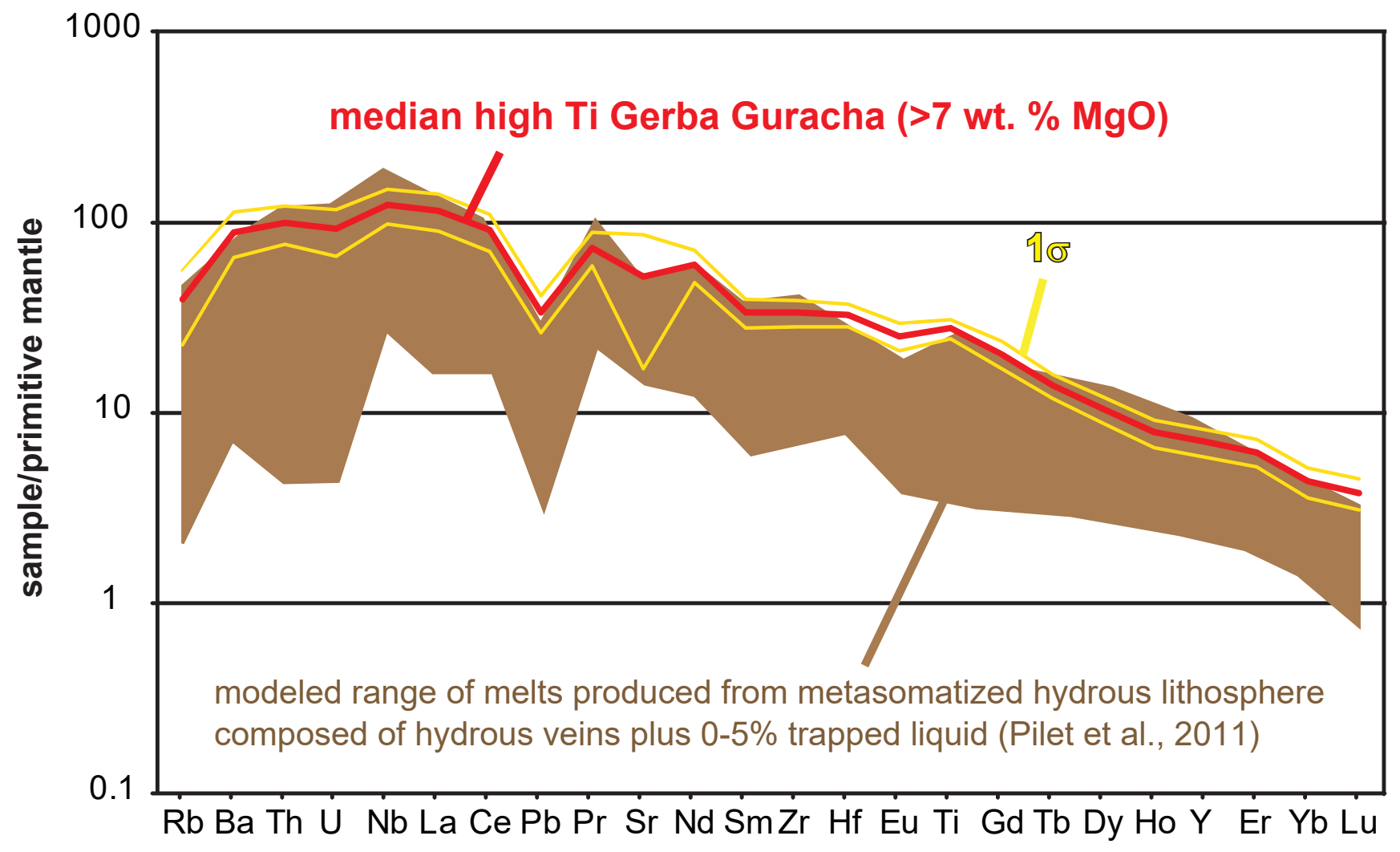



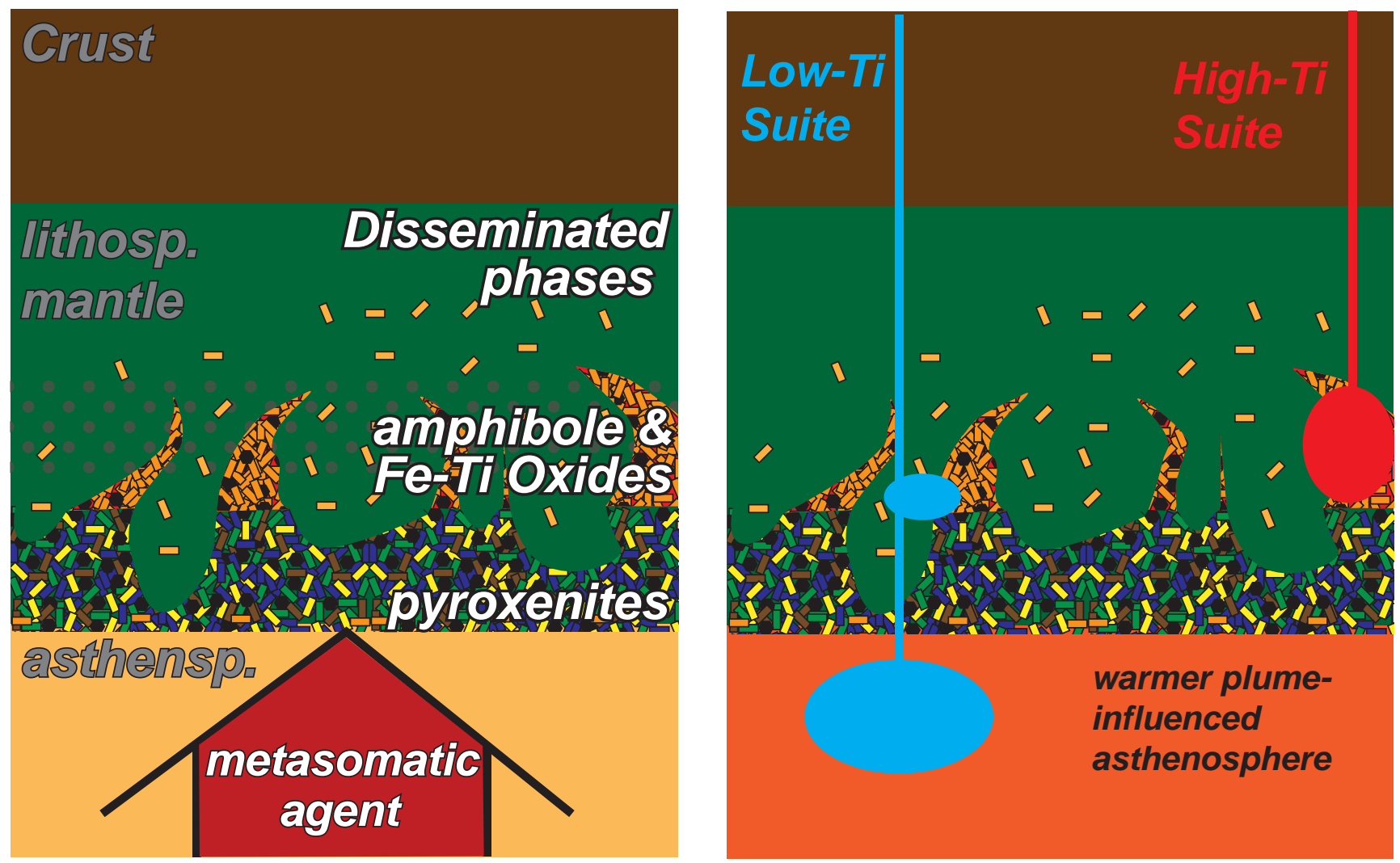